San Jose State University

SJSU ScholarWorks

Master's Theses

Master's Theses and Graduate Research

Summer 2013

\title{
A Study of Genetic Variability in Larval and Adult Populations of Dungeness Crab (Cancer Magister)
}

Cairbre Fanslow

San Jose State University

Follow this and additional works at: https://scholarworks.sjsu.edu/etd_theses

\section{Recommended Citation}

Fanslow, Cairbre, "A Study of Genetic Variability in Larval and Adult Populations of Dungeness Crab (Cancer Magister)" (2013). Master's Theses. 4336.

DOI: https://doi.org/10.31979/etd.97zd-yrdq

https://scholarworks.sjsu.edu/etd_theses/4336

This Thesis is brought to you for free and open access by the Master's Theses and Graduate Research at SJSU ScholarWorks. It has been accepted for inclusion in Master's Theses by an authorized administrator of SJSU ScholarWorks. For more information, please contact scholarworks@sjsu.edu. 


\author{
A Thesis \\ Presented to \\ The Faculty of the Department of Biological Sciences \\ San José State University \\ In Partial Fulfillment \\ of the Requirements for the Degree \\ Master of Science
}

by

Cairbre Fanslow

August 2013 
(C) 2013

Cairbre Fanslow

ALL RIGHTS RESERVED 
The Designated Thesis Committee Approves the Thesis Titled

\title{
A STUDY OF GENETIC VARIABILITY IN LARVAL AND ADULT POPULATIONS \\ OF DUNGENESS CRAB (CANCER MAGISTER)
}

\author{
by \\ Cairbre Fanslow \\ APPROVED FOR THE DEPARTMENT OF BIOLOGICAL SCIENCES \\ SAN JOSÉ STATE UNIVERSITY
}

August 2013

Dr. Leslee Parr, Department of Biological Sciences

Dr. Joshua Mackie, Department of Biological Sciences

Dr. Shannon Bros-Seemann, Department of Biological Sciences 


\begin{abstract}
A STUDY OF GENETIC VARIABILITY IN LARVAL AND ADULT POPULATIONS

OF DUNGENESS CRAB (CANCER MAGISTER)
\end{abstract}

by

Cairbre Fanslow

Spatial and temporal genetic variation was assessed using mitochondrial DNA from adult and megalopae of Dungeness crabs, Cancer magister, from Fraser Delta in British Columbia, Washington, Oregon, and California. Megalopae were continuously sampled using light traps in one location, Coos Bay, Oregon, and compared with adults sampled across the species' range. While small-scale spatial and temporal variation were evident, there was no significant fit to the Isolation-by-Distance model when considering adult and larvae populations sampled over a coastal length of $\sim 1700 \mathrm{~km}$ (Mantel $r=$ 0.059, $\mathrm{p}=0.289$ ). Smaller bays showed higher genetic diversity than larger bays, contrary to typical expectations. MtDNA diversity measures (assessed by canonical correlation analysis) were correlated with bay size and depth, suggesting that hydrological patterns or fishing harvests in local areas (or a combination of both) influenced the observed genetic signature. The Dungeness crab ancestral population likely went through a historic population expansion associated with recent glacial relaxation, as evidenced by mismatch distributions and predominance of singleton haplotypes. In larval samples, we commonly observed numerous individuals of a haplotype, which suggests that families of larvae remain aggregated during dispersal. Sampled offspring revealed a low fraction of the adult gene pool (in accordance with the Hedgecock effect), yet high variability in recruitment over time. A realized long distance dispersal of larvae and the additive effects of recruitment from different sources over time may have prevented significant genetic differentiation within the $C$. magister range. 


\section{ACKNOWLEDGEMENT}

Foremost, I would like to thank my family, Jenn and Avery, for their patience, understanding, sacrifice, and for forgiving me during my stress-induced rambling about crabs, stats, and editing. I want to give thanks to my extended family for their contributions and sometimes just a sympathetic ear.

I would also like to thank my thesis committee for their patience, experience, insight, and thoroughness in helping me to better myself and in becoming a marine biologist. In particular I would thank Dr. Leslee Parr for access to her lab, for her mentorship, and for her connections with Dr. Alan Shanks, without whom I would not have samples to test. Dr. Shannon Bros-Seemann I thank for her insight into ecology and invaluable writing and editing help. To Dr. Joshua Mackie, I have sincere thanks for his

dedication to pulling me, kicking and screaming, through the analyses of complex genetic and evolutionary relationships and his friendship. Congratulations again on your wedding nuptials. Also, I would like to give a special thanks to Brian Barney and Dr Alan Shanks for their sample contributions without which I would not have data.

Lastly, I would like to thank San Jose State University and the Biology Department for their support and the wonderful teachers I have met and studied under. The Michael Lee Environmental Foundation provided additional financial support for this thesis. 


\section{TABLE OF CONTENTS}

LIST OF FIGURES ................................................................................. viii

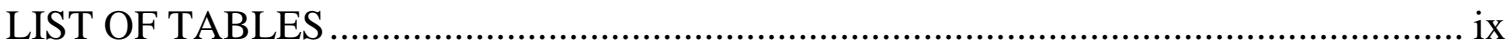

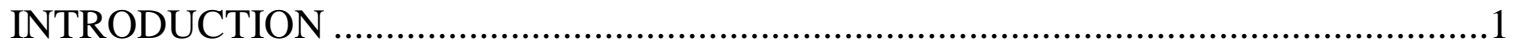

Research system and goals ............................................................................

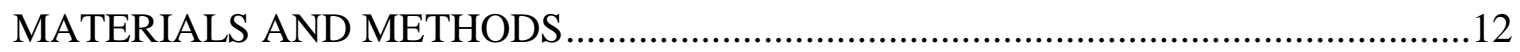

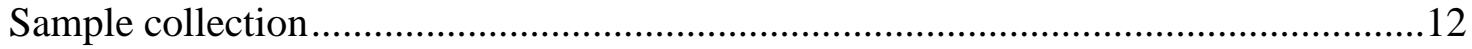

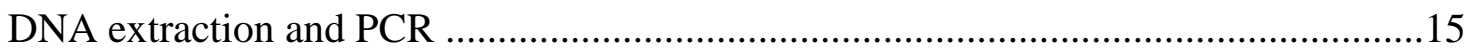

Characterization and submission of sequence data ..............................................16

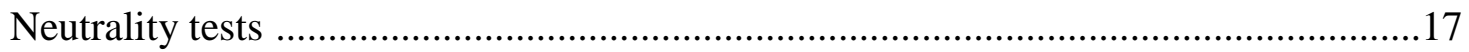

The mismatch distribution - a metric sensitive to historic population expansion .......18

Measurement of population differentiation ........................................................19

Tests for spatial differentiation: Exact and Mantel tests ........................................22

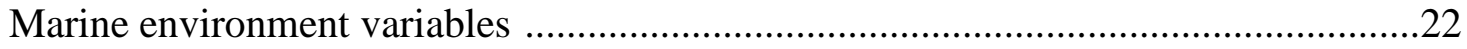

Examination of the association between genetic and environmental variables ..........27

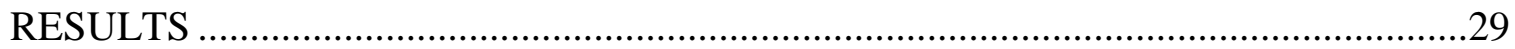




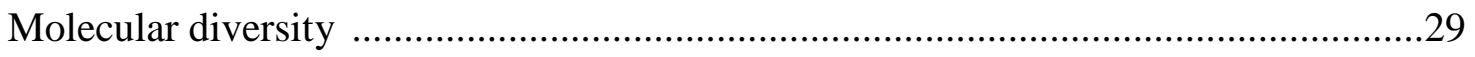

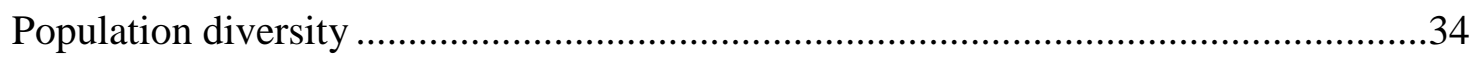

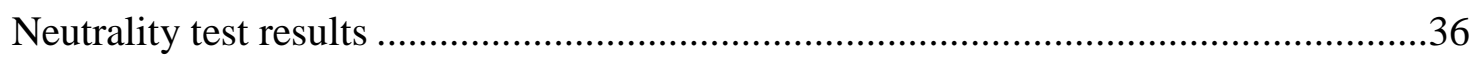

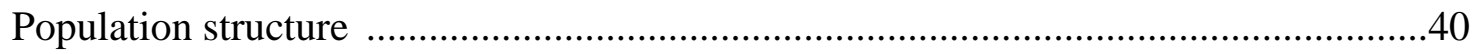

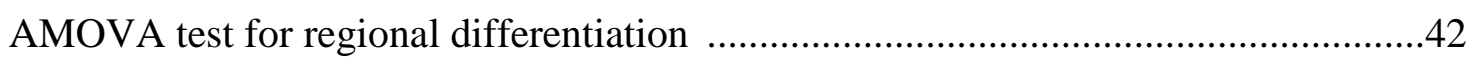

AMOVA based comparisons of megalopae sampled at different times ....................43

Consideration of diversity measures and environmental variables $\quad$..........................45

Canonical correlation comparison of environmental and genetic relationships $\quad$.........52

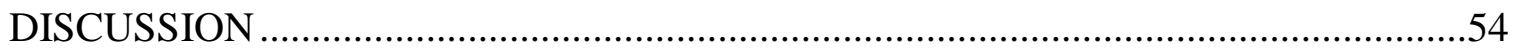

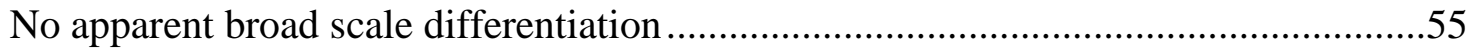

High genetic variance among larval collections ..................................................56

Inverse correlation among bay size and genetic diversity ....................................57

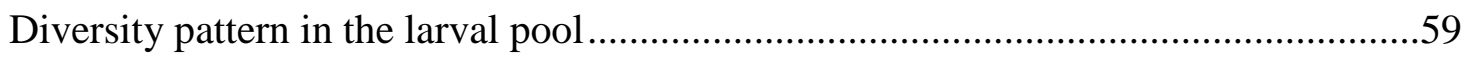

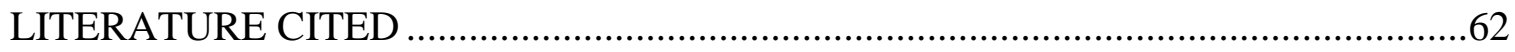




\section{LIST OF FIGURES}

Figure \#

Page

Figure 1. North American coastline with inserts showing the sample sites ..............13

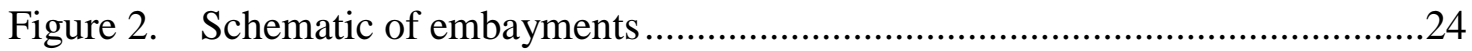

Figure 3. Diversity pie charts and collection inserts of embayments ......................35

Figure 4A. The mismatch distribution of COI sequences obtained from adult

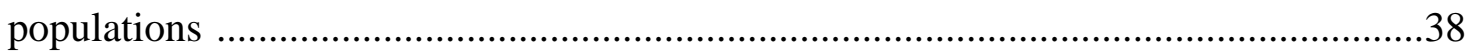

Figure 4B. The mismatch distribution of COI sequences obtained from megalopae ...38

Figure 5. Plots of genetic diversity measures and environmental parameters ............49

Figure 6. Plot of embayment opening sizes versus $F_{\mathrm{ST}}$. ....................................51

Figure 7. Canonical Correlation Analysis of diversity measures and habitat measures 53 


\section{LIST OF TABLES}

Table \#

Page

Table 1. Cancer magister adult and larval population samples ............................14

Table 2. Regional groupings used in AMOVA ...............................................21

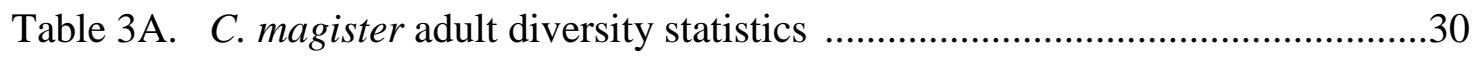

Table 3B. C. magister megalopae diversity statistics ..........................................31

Table 4. Distribution of haplotypes found in megalopae populations ....................33

Table 5A. A pairwise $F_{\mathrm{ST}}$ matrix for adult $C$. magister populations ..........................40

Table 5B. A pairwise $F_{\text {ST }}$ matrix for megalopae samples ..................................41

Table 6. AMOVA tests of alternative spatial and temporally based comparisons ...43

Table 7. Reported turbidity measurements ...................................................46

Table 8. Physical and genetic measurements from collection sites ......................47

Table 9. Statistical description of Skewedness .................................................47 


\section{INTRODUCTION}

Determining accurate dispersal scales and other mechanisms that affect population structure is essential for establishing policy management in marine environments (Palumbi 2003, Botsford et al. 2003, Trakhtenbrot et al. 2005). The question of whether marine environments are open systems, interconnected systems, or closed systems in terms of gene flow is still debated (Cowen et al. 2000, Warner \& Cowen 2002, Sotka et al. 2004). Relevance of whether or not marine environments are open helps shape marine reserve design (Palumbi 2003) and helps determine the impact on fisheries and stock management. Understanding the dispersal of the juvenile larvae is critical to the question of marine conservation. Tracking larvae directly is not usually possible and populations are more often analyzed by observing the recruitment stage (Shanks et al. 2003), by modeling of passive particles (Kinlan \& Gaines 2003, Sotka et al. 2004, Kinlan et al. 2005), or by inference using genetic markers (Palumbi 2003, Hellberg et al. 2001). Combining genetic diversity measures with ecological and biogeographic measures has been more recently established in the field of landscape genetics (Manel et al. 2003), and now “seascape” genetic studies (Galindo et al. 2006, Selkoe et al. 2008). Predicting the realized gene flow in species with long pelagic larval durations is particularly difficult. The duration larvae spend in the water column and the potential dispersal distances are likely important factors in the genetic structure of marine organisms. The major method of understanding larval dispersal, and thereby population connectivity, is through genetic markers (e.g., Wright 1943, Weir \& Cockerham 1984, 
Avise et al. 1987, Warner \& Cowen 2002). The use of genetic markers to establish phylogeographically patterns of gene flow within a species' geographic range has a long history (Avise et al. 1987, Hellberg 2009). Over time, genetic changes have accumulated, indicating complex patterns of dispersal more than passive drifting could explain (Palumbi 1994, Galindo et al. 2010). As evidence of complex dispersal has accumulated, genetic markers in species with long planktonic duration have often shown genetic breaks occur over short distances (Kelly \& Palumbi 2010).

Larval behavior, perhaps as importantly as pelagic duration, is an important aspect of population dynamics. Active swimming behaviors of larvae, such as vertical migration, are the primary means by which many species avoid some tidal actions or rapid surface currents (McLaren 1963, and for C. magister, Shanks 1986, Pillar et al. 1989). Oceanographic features, such as tidal forces and upwellings, have been correlated with larval distribution (Shanks et al. 2003). Tidal and upwelling correlations can then be used to provide spatial models to estimate larval distribution. In predicting population dynamics, further biological and oceanographic factors need integration. Factors that need to be considered include the fecundities of organisms and ecosystem productivity, which in at any given time affect spatial densities of recruiting populations and seasonal or yearly variability in current pattern (Shanks et al. 2003; Cowen \& Sponaugle 2009).

As an example of important marine geographic barriers, Wing et al. (1995) revealed how currents around Pt. Reyes and Pt. Arena, California cause offshore accumulation of crab larvae during seasonal upwelling; after accumulation - during upwelling relaxation events - larvae then tend to be transported back to the vicinity of 
origin. Point Conception in Southern California is a one of the most highly studied biogeographic barriers (Burton 1998, Dawson 2001). Here, numerous case studies reveal diverse evolutionary dynamics. There are cases of species in which dispersal breaks occur at Point Conception and cases of ecologically similar species showing genetic connection across this zone (Palumbi 1994, Hellberg 1996, Burton 1998, Dawson 2001). In a study of three limpet species over shorelines of multiple Hawaiian islands, Bird et al. (2007) found stronger evidence of zonal genetically segregation across intertidal-sub tidal depth zones than between islands. Case studies, such as those described by Bowen et al. (2006), indicate that pelagic duration correlated poorly with genetic subdivision and that the importance of ecological variables may determine genetic structure.

A number of studies have countered the simple "rule" that long distance dispersal should predictably lead to genetic cohesion. Johnson and Black (1982) found a shifting, “chaotic” genetic patchiness among planktonic dispersing limpets from Western Australia. This reported genetic patchiness found in allozyme markers was one of the first examples of the unevenness of population structure in an apparently open marine system. Doherty et al. (1995) also found that genetic variability among seven fish species sampled throughout the Great Barrier Reef that did not match an Isolation-by-Distance model. Sotka et al. (2004) found that acorn barnacles in the rocky intertidal communities of the Pacific Ocean show strong population division in the region of central California but not in Southern California, or Northern California, or Oregon. As a whole, population differentiation can be influenced by a mixture of larval behavior, ecological 
impact, and especially reproductive success, all of which contribute to the unique genetic signature in long-distance dispersal species.

It is generally not expected that all individuals in a population contribute equally to reproduction simultaneously. Temporal variation in larval success, where a small fraction of the reproducing adult population is represented each year due to oceanic variability and high larval mortality, may explain genetic patterns present within a species at any given moment. Hedgecock (1994), considering demographics in terms of effective population size, $N_{\mathrm{e}}$, and census population size, $N$, illuminated the point that a relatively small proportion of adults may account for the bulk of reproduction at one time, particularly in broadcast spawners. The process also envisions organisms as having relatively few "winners," that is, successful breeders, and many "losers" in reproduction (Hedgecock \& Pudovkin 2011). The idea has gained interest, and a "sweepstake" reproduction pattern is often referenced to describe genetic variance in highly fecund marine species (Li \& Hedgecock 1998, Turner et al. 1999, 2002, Flowers et al. 2002).

In systems in which genetic variance in the gamete or larval pools vary strongly over time, seasonal variations are likely to be important in determining the genetic variance accruing in and among populations. The "sweepstake theory" predicts that species, though they may be broadly dispersed, are not necessarily highly similar in genetic structure.

In agreement with the sweepstake idea, Turner et al. (1999) and Flowers et al. (2002) both found that recruitment-level variation impacted population structure, even overcoming small selective advantages and disadvantages (fitness variation) of alleles. 
Flowers et al. (2002) researched variance in reproductive success contributing to each larval cohort in the sea urchin, Strongylocentrotus purpuratus, evaluating 348 mitochondrial sequences. They observed high temporal genetic variance, as larval populations were genetically and statistically distinguishable when compared across years, and estimates of $N_{\mathrm{e}}$, the effective number of breeding females, were generally low compared to the census population size. Similarly, in a study of Red Drum, Sciaenops ocellatus, an estuarine fish, Turner et al. (1999) found evidence of genetic drift changing the genetic signature in different years (1986-89), from which they determined that the effective (female) population size was small in each year.

As Turner et al. (1999) showed, temporal variance in the $N_{\mathrm{e}}$ can be quite high between years. These studies emphasize that assumed genetic variance is temporarily stochastic. Models that assume an equilibrium $N_{\mathrm{e}}$ measure (such as the gene flow-drift equilibria model) would be unrealistic in species with yearly variance in reproductive conditions. The question remains, can annually changing oceanographic and reproductive conditions explain more of genetic variance in broad spawning species than a genetic model based on distance?

\section{Research system and goals}

The goal of this thesis was to compare populations of the Dungeness crab, Cancer magister, in space and over time using cytochrome c oxidase subunit 1 (COI) nucleotide sequences to determine how population diversity varies along the coastline and to assess whether there are genetic discontinuities that are relevant to stock management. 
Cancer magister, which is sometimes referred to taxonomically to the genus Metacarcinus (Ng et al. 2008), occurs along the western Pacific coastline of North America from the Aleutian Islands, Alaska, to Baja California, Mexico. The commercial range extends from Alaska through the Puget Sound, south along Washington and Oregon, ending in Southern California (Jensen \& Armstrong 1987, Pauley et al. 1989). C. magister is common at depths of $<100 \mathrm{~m}$ along the shelf, occurs within shallow marine estuaries on the North American Pacific coastline, and occurs at lower density in Southern California. Wild (1980) suggested that low C. magister abundance in Southern and Baja California is a consequence of poor adaptation to higher water temperatures.

Detection of genetic patterns through genetic markers has generally increased understanding of population differentiation. The COI gene in particular has been used frequently in intra-specific genetic variation studies (Avise et al. 1987, Barber et al. 2002, Waples et al. 2008, Bucklin et al. 2011). Population connectivity can be tracked due to the similarity of haplotypes defined by the (usually silent) nucleotide substitutions seen in this mitochondrial DNA segment. Examples of genetic differentiation using the genetic marker COI include the Eurasian perch, Perca fluviatilis, (Bergek and Olsson 2009); copepods along the California coastline, Tigriopus califorinicus, (Burton 1998); the barnacle Balanus glandula within rocky intertidal zones (Sotka et al. 2004); and in a wide range of marine species along the Western coastline of North American (see Kelly \& Palumbi 2010). 
Utilizing collections of adult and megalopae stage crabs and COI analysis, this thesis examined spatial gene flow over large and small scales and secondly, annual variance in larval populations was examined, comparing 6 (non-consecutive) years of larvae collected at a range of locations, with intensive sampling at Coos Bay, Oregon.

It is still generally difficult to predict whether gradual patterns of genetic divergence (isolation-by-distance), or sharp, barrier-associated disjunctions are present in a given organism's range. In the context of the Pacific Ocean, it is relevant to ask whether long duration pelagic dispersers avoid barriers or whether there are more localized patterns influencing a species’ genetic disjunction.

The Dungeness crab was selected as a model invertebrate to study larval dispersal because it has high fecundity, long reproductive life, and long-range larval dispersal. The crabs live for an average of 8 to 10 years and reach effective breeding age by 2 years (Pauley et al. 1989). Adult males (which embrace females during reproduction and hold fast for up to a week) covet premolt females. Females typically produce 2 million eggs, but production can reach an estimated 5 million eggs (Pauley et al. 1989, Fernandez et al. 1993). Egg release generally occurs generally between December and April, depending on latitudinal temperature variation (Wild 1980, Moloney et al. 1994). The long distance dispersal capability of Dungeness crab larvae (Shanks 2006, Shanks 2009) may reflect a general adaptation favored by oceanic variability. After eggs hatch and become planktonic, tidal forces carry the larvae out of bays and estuaries onto the continental shelf. C. magister larvae undergo up to 5 months of development in the open ocean 
through five zoeal stages, with the megalopae being the last stage before molting into recognizable juveniles (Roegner et al. 2003). C. magister is a predator throughout its life cycle, feeding in the open ocean carnivorously on plankton and then as adults on bivalves, mollusks, fish, and even on smaller C. magister (Pauley et al. 1989).

After the transition from larvae to megalopae, the megalopae recruit back to estuaries and coastal sites along the Pacific Coast range. "Recruiting” cohorts are generally defined as those surviving after the zoeal development when megalopae are returning to various sites along the coast. Recruits are dispersed to the continental shelf by upwelling currents and atmospheric pressures acting on ocean currents and then back to shore by using the same hydrological processes (Shanks \& Roegner 2007). C. magister megalopae recruitment may depend on specific temperatures before entering estuaries in high abundance from April through September (Pauley et al. 1989). Within a few months, megalopae arrive along the coast and enter estuaries in distinct pulses interspaced with periods of low or zero abundance (Fernandez et al. 1993, Roegner et al. 2003, Shanks \& Roegner 2007). After recruitment to suitable habitats, megalopae develop into juveniles. Juveniles settle in $<20$-meter deep benthic habitats along the open coastline or within estuaries; however, the mechanisms for crab recruitment into estuaries are not well understood (Roegner et al. 2003).

Toonen and Grosberg (2003 unpublished: report to California SeaGrant) set out determine whether Cancer magister showed geographic structure or whether there were differences in the haplotypes of recruiting sets of larvae. While many microsatellites were isolated, the authors did not find large enough populations of $C$. magister to study 
effectively. In the same work, the authors reported findings for another species, the porcelain shore crab, Petrolisthes cinctipes, which indicated a lack of geographic spatial pattern. The authors also found that while there are differences in the genetic patterns of separately collected samples of larvae, the differences were dampened over time, as multiple sets of recruits arrive.

In a study of COI sequences from eight populations of a common shoreline crab, Hemigrapsus oregonensis, Petersen (2007) found differences indicating barriers to dispersal among the northern and southern regions, corresponding to Cape Blanco (approximately the California and Oregon state boundary). COI haplotypes overall had wide ranges of distribution, indicating that since post-glacial range formation, there has been long distance dispersal, yet some restriction across Cape Blanco was observed. Petersen referred to the Cape Blanco area as a "semi-permeable” barrier. The contribution of recent dispersal events (including patterns driven by El Niño patterns, for example) versus the effect of historic isolation patterns has not yet been quantified in many cases. Statistics that are sensitive to haplotype frequencies in combination with phylogeny, such as Tajima's $D$ and the mismatch distribution (explained below), showed distinguishable patterns in the northern and southern $H$. oregonensis populations. Northern populations had more endemic haplotypes, whereas the signature of the southern area was consistent with an entire population expansion into the area following the most recent ice age. H. oregonensis reportedly has a 3-4 week planktonic larval duration. Petersen argued that long-duration-larval (six week or more) species such as $C$. 
magister may show no population structure and no evidence of ancestral refuges shaping diversity (Petersen 2007).

C. magister has been the subject of a number of genetic studies, including unpublished theses. While generally examining small regions of the range, studies have demonstrated homogeneity in regional scale analysis of population structure (Dedhia 2005 unpublished thesis, SJSU, Lardy 2006 unpublished thesis, SJSU, Beacham et al. 2008, Barney 2012 unpublished thesis, SJSU) found that genetic connection is generally high among populations sampled from California to Washington.

In a study of 10 Puget Sound sample locations, Beacham et al. (2008) sampled between 23 and 119 adult crabs per site and analyzed microsatellites. They found that the C. magister sampled around Victoria Island, British Columbia, were genetically homogenous, and only one sampled site, Alison Sound, had local differentiation (overall $F_{\mathrm{ST}}=0.031$; no p-value given). Beacham et al. (2008) speculated that narrowness and shallow depth of the channel leading into Alison Sound constrained the water volume exchange and accounted for a high level of larval retention in the single subdivided population. A test for isolation-by-distance revealed no discrete population division from Northern to Southern British Columbia despite diverging seasonal currents around Vancouver Island. Dedhia (2005) and Lardy (2006) studying adult Cancer magister populations both found high haplotype diversity (finding 350 unique haplotypes among 846 individual COI sequences) and low but significant genetic differentiation among populations. Barney (2012), using 445 sampled adults from British Columbia to Southern California, found that there was no significant population structure, or isolation- 
by-distance pattern, but found a large number of site-specific mtDNA haplotypes; (of the 302 base pairs sequenced, gene diversity was relatively high, ranging from $h=0.6$ to 0.8 ). This study, being the largest in terms of sample size and sampled range, found little restriction to gene flow.

The major goal of the present study was to examine population dynamics of $C$. magister by considering genetic analysis of larval samples and genetic patterns in adult population samples. Using COI sequences, we assessed the following questions below. (i) We examined collections of adults and tested for isolation-by-distance across the range.

(ii) Larval samples collected during the spawning period of April through September in 2001, 2003, 2008, and 2009 in one location, Coos Bay, Oregon, were used to determine whether pools of recruits are genetically mixed populations or not. (iii) Analyses of genetic diversity measures were conducted to determine whether ocean currents or other localized factors (e.g., bay size, commercial catch) impact population genetic signatures. 


\section{MATERIALS AND METHODS}

\section{Sample collection}

Adults. We obtained 296 adult C. magister samples from British Columbia, Washington, Oregon, and California (Figure 1), mostly from commercial catches, with a smaller proportion donated by local commercial fishermen, seafood markets/distributors, and scientists (Dedhia 2005, Lardy 2006, Barney 2012). Crabs were caught using standard circular crab traps (Dahlstrom \& Wild 1983, Lardy 2006). Generally, a single leg was removed from each individual. In the case of live crabs, non-lethal sampling was employed. A fifth-walking leg was held firmly until the crab autotomized it. This approach minimizes the risk of excessive bleeding (Lardy 2006). In some cases, loose legs that had been lost by crabs while in traps or in holding tanks were included in the samples. To avoid accidental sample duplication, legs from the same source were sorted, and only those legs of the same size, from the same side of the body were used. Nevertheless, commercial fishermen stated that they rarely observed crabs missing more than one leg (Dr. L. Parr pers. comm.). In one case, over 200 legs and claws were donated from a single commercial fishing company in San Francisco, and a random sample of 53 was taken by using a random number generator (Lardy 2006).

One challenge to the methodology of adult sampling might be a lack of precise source location determination. The adult C. magister samples were non-randomly, opportunistically sampled through out the inlets illustrated in Figure 1. The sample locations included 3 potential areas: 1) the dockside of the nearest marina, 2) throughout 
the bay, and 3) outside the bay on the open continental shelf, where local fishermen reported they had collected samples.

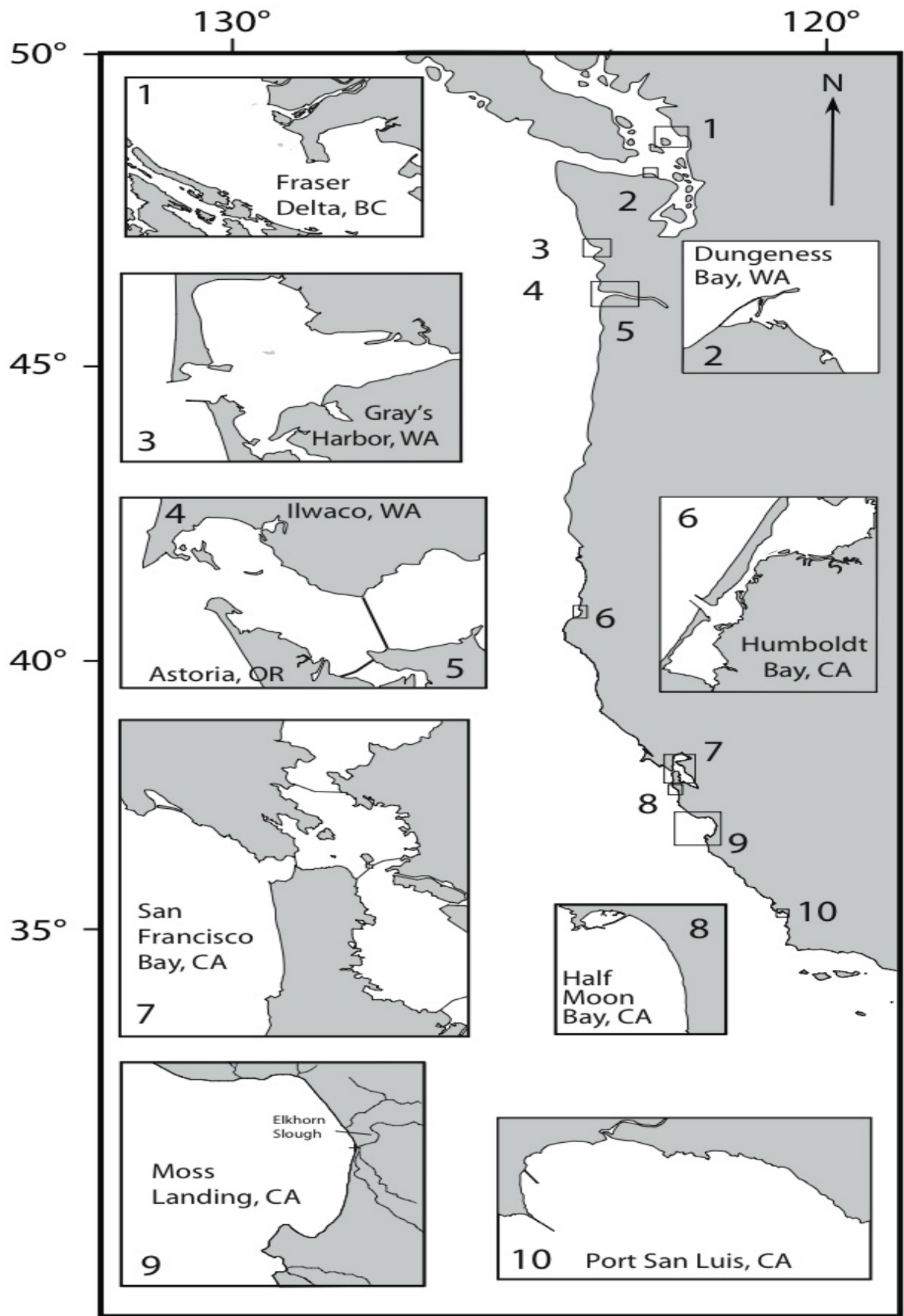

Figure 1. North American coastline with inserts showing the shoreline of sample sites. Graphics: Lynn McMasters. 
Latitude and longitude coordinates were found using Google Earth 6.1, and distances were measured following a coastline trace at 100 feet altitude. In addition to COI sequence data reported here, sequences generated by previous graduate students (Dedhia 2005, Lardy 2006, Barney 2012) were compared to ascertain a more complete picture of Dungeness crab population structure.

Table 1. Cancer magister adult and larval population samples. Approximate geographic position < 2km; collector: Bryan Barney (B) or Alan Shanks (A).

\begin{tabular}{|c|c|c|c|c|}
\hline Site & Year & $\mathbf{n}$ & GenBank accessions & Collector \\
\hline $\begin{array}{l}\text { Fraser Delta, British } \\
\text { Columbia }\end{array}$ & 2009 & 25 & JX097359 - JX097384 & B \\
\hline $\begin{array}{l}\text { Dungeness Bay, } \\
\text { Washington }\end{array}$ & 2009 & 24 & JX097385 - JX097409 & B \\
\hline $\begin{array}{l}\text { Gray's Harbor, } \\
\text { Washington }\end{array}$ & 2009 & 25 & JX097409 - JX097434 & B \\
\hline Ilwaco, Washington & 2009 & 25 & JX097435 - JX097459 & B \\
\hline Astoria, Oregon & 2004 & 24 & JX097460 - JX097484 & A \\
\hline Eureka, California & 2005 & 25 & JX097485 - JX097510 & A \\
\hline $\begin{array}{l}\text { San Francisco, } \\
\text { California }\end{array}$ & 2005 & 53 & JX097511 - JX097564 & A \\
\hline $\begin{array}{l}\text { Half Moon Bay, } \\
\text { California }\end{array}$ & 2005 & 36 & JX097565 - JX097601 & A \\
\hline $\begin{array}{l}\text { Moss Landing, } \\
\text { California }\end{array}$ & 2005 & 30 & JX097602 - JX097632 & A \\
\hline $\begin{array}{l}\text { Port San Luis, } \\
\text { California }\end{array}$ & 2005 & 29 & JX097633 - JX097662 & A \\
\hline Coos Bay, Oregon & 2001 & 135 & JX097663 - JX097798 & A \\
\hline Coos Bay, Oregon & 2003 & 60 & JX097799 - JX097859 & A \\
\hline Coos Bay, Oregon & 2008 & 169 & JX097860 - JX098026 & A \\
\hline Coos Bay, Oregon & 2009 & 33 & JX098027 - JX098060 & A \\
\hline
\end{tabular}


Megalopae. This study generated COI sequences from 406 megalopae-stage $C$. magister. Larval crabs were continuously sampled using light traps at the mouth of Coos Bay, exploiting the positive phototropism of megalopae towards artificial illumination (Miller \& Shanks 2004, Roegner et al. 2007). Larvae were collected every few days and donated by Dr. Alan Shanks of the Oregon Institute of Marine Biology, Charleston, OR, from the Charleston Marina Coast Guard station pier in Coos Bay, OR, estuary at Long: $43^{\circ} 20^{\prime} 12^{\prime} \mathrm{N}$ by Lat: $124^{\circ} 19^{\prime} 14^{\prime \prime} \mathrm{W}$ following the techniques outlined in Roegner et al. (2007). In total, 406 megalopae larvae of C. magister were sequenced for COI spanning 4 non-concurrent years. Years 2001 and 2003, were examined by previous graduates Dedhia (2005) and Lardy (2006) while sequences for megalopae collected in 2008 and 2009 were newly generated.

\section{DNA extraction and PCR}

Samples were held frozen $\left(-20^{\circ} \mathrm{C}\right)$ for up to two years prior to DNA extraction and Polymerase Chain Reaction (PCR) amplification. DNA was extracted from leg muscle of adults, or from the whole organism for megalopae, using the Promega Wizard ${ }^{\circledR}$ Genomic Purification Kit Catalogue \# A1125, following manufacturer’s instructions. Extracted DNA was rehydrated in $50 \mu \mathrm{l}$ of TE buffer and stored at $-20^{\circ} \mathrm{C}$.

PCR amplified a 359 base-pair amplicon, corresponding to positions 1718-1777 within the COI gene using primers designed specifically for C. magister (Harrison and 
Crespi 1999). The forward primer was S1718b (5'-GGAGGATTTGGAAATTGATT -3), and the reverse was 'AS2097 (5'-GTACAGGAAGGGATAGTAGT-3'). For statistical analysis, we used a common 338- base pair region for adults and a 222-base pair region for megalopae.

PCRs were conducted in $25-\mu 1$ volumes, containing $2 \mu \mathrm{l}$ of DNA dilution, $1 \mathrm{X}$ PCR Buffer (Finnzymes), $0.2 \mathrm{mM}$ dNTPs (Qiagen), $0.2 \mu \mathrm{M}$ forward and reverse primers (Operon), $0.4 \mathrm{mg} / \mathrm{ml}$ bovine serum albumin (BSA) (Promega), $3.0 \mathrm{mM} \mathrm{MgCl} 2$ (Promega), and 1 unit Taq polymerase (Finnzymes). The BSA was added to counteract the PCRinhibiting affects of seawater (Kreader 1996). PCRs were run on a Personal Thermal Mastercycler (Eppendorf International, Hamburg, Germany): 5 min at $94^{\circ} \mathrm{C}$, followed by

a "touchdown" steps of 10 cycles of $30 \mathrm{~s}$ at $94^{\circ} \mathrm{C}$ and $45 \mathrm{~s}$ at $55^{\circ} \mathrm{C}$, reducing by $0.5^{\circ} \mathrm{C}$ every cycle, $1 \mathrm{~min}$ at $72^{\circ} \mathrm{C}$, then another 30 cycles of $30 \mathrm{~s}$ at $94^{\circ} \mathrm{C}$, 45 s at $50^{\circ} \mathrm{C}$, and $1 \mathrm{~min}$ at $72^{\circ} \mathrm{C}$, and a final extension of $72^{\circ} \mathrm{C}$ for 5 min. Products were checked electrophoretically on a 2\% ethidium-labeled agarose gels to check for specificity of amplification.

\section{Characterization and submission of sequence data}

PCR products were cleaned following instructions in Qiagen QIA Quick PCR purification kit \#51504. Purified PCR products were sent to Geneway, LLC, at Hayward, CA for sequencing. Sequencing was conducted on an ABI Prism Model 377 (version 3.2) automated sequencer using Big Dye chemistry (Applied Biosystems). Sequences 
were aligned and verified for accuracy of trace files and the removal of ambiguous bases, using Mega4 (Tamura et al. 2007).

Molecular data indices were calculated for population samples using the software Arlequin 3.5 (Excoffier \& Lischer 2010). Diversity measurements included gene diversity $(h)$, which is the probability that two random sequences taken from the same population will differ by at least one nucleotide, and nucleotide diversity $(\pi)$, the average genetic distance between pairs of sequences (Nei 1986). Kimura-2 parameter distance was used in $\pi$, correcting for multiple substitutions per site while taking into account different rates or occurrence of transitions and transversion mutations (Kimura 1980). Once sequenced, all COI data sets were submitted to Genbank and received accession numbers JX097359 to JX097662 for adults and accessions JX097663 to JX098060 for megalopae (Table 1).

\section{Neutrality tests}

Fu’s $F_{S}(F u$ 1997) and Tajima’s $D$ (Tajima 1989) are techniques to detect departures from neutrality or deviations due possibly to historic change in population size (groups of observations that themselves may not be distinguishable). Fu's $F_{\text {S statistic }}$ indicates the presence of an excessive number of rarer and singleton alleles in populations. Negative scores of Fu's $F_{S}$ test may signal population expansion (Fu 1997). Tajima's $D$ scores are used to test the assumption of selective neutrality of mutations among COI sequences (Tajima 1989). In the absence of strong selection and with a historically, stable population size and a constant rate of mutation, $D$ and $F_{\mathrm{S}}$ have 
predictable equilibrium values. A test of significance for the $D$ and $F_{\mathrm{S}}$ values were calculated from the infinite allele equilibrium relationship following Fu and Li’s (1993) methodology outlined in Excoffier and Lischer article (2010). Populations that have gone through a bottleneck or founder effect in their recent past have characteristically negative $D$ and $F_{\mathrm{S}}$ values (Mousset et al. 2004). Given results in a similar species in this region (Petersen 2007), we expect that Tajima's $D$ and Fu's $F_{S}$ scores for $C$. magister will be negative, assuming the population is expanding possibly from a recent bottleneck after the most recent glacial relaxation.

\section{The mismatch distribution - a metric sensitive to historic population expansion}

The mismatch distributions (a histogram of the numbers of mutational differences between pairs of haplotypes) were also used to test whether mutational distances among alleles could fit the "sudden expansion model” (Rogers \& Harpending 1992). The mismatch distribution was also used to calculate $r$, the "raggedness" index (Harpending 1994). A low "raggedness" index value $(<1)$ would indicate a rejection of the fit between the observed distribution and the statistical model. Here, a p-value was determined by the sum of square deviations (SSD) test between the observed and the expected mismatch as a test statistic model (see Excoffier \& Lischer 2010).

The mismatch is usually multi-modal in samples drawn from populations at demographic equilibrium, as it reflects the highly stochastic shape of gene trees, while it is usually uni-modal in populations having passed through a recent demographic expansion (Slatkin 1991, Rogers \& Harpending 1992). Typically, multi-modal mismatch 
distributions have large values of $r$; uni-modal wave distributions typically have low values $(<1)$ of $r$.

To compare estimates of when adult and larval populations underwent recent population expansions, we calculated mismatch distributions to compared rates of population expansion (Harpending 1994; Rogers 1995). For expanding populations, we converted the parameter tau ( $\tau$; calculated from the mismatch distribution) estimating time since population expansion (t) via the equation $\tau=2 u t$, where $u=\mu k$, where $\mu$ is the mutation rate per site per year, and $k$ is the sequence length (Rogers 1995; also see Schneider \& Excoffier 1999). We estimated $t$ using a mutation rate $(\mu)$ of $2.3 \%$ per million years times the COI sequence for adults and larvae, estimated for a sample of Decapoda (Knowlton \& Keller 1993, Knowlton \& Weigt 1998). The lower and upper 95\%-confidence intervals of $\tau$ were calculated using a parametric bootstrap approach (Schneider \& Excoffier 1999).

\section{Measurement of population differentiation}

Populations were assessed for genetic difference using pairwise $F_{\mathrm{ST}}$ and hierarchal ordering using an analysis of molecular variance (AMOVA) (Excoffier et al. 1992) in Arlequin 3.5. AMOVAs were used to determine if there were genetic differences among adult populations and then again for megalopae across sampled years. Genetic differences among individuals were estimated by pairwise $F_{\text {ST }}$ statistics over all loci (Weir \& Cockerham 1984, Slatkin 1985) from the COI aligned sequences. The fixation indices were estimated using Kimura’s 2-parameter distances among sequences 
(Kimura 1980). Significance was determined in Arlequin 3.5 using 10,100 replicates, where $\mathrm{p}$ is estimated as the proportion of randomized permutations, of $F_{\mathrm{ST}}$ larger or equal to the observed $F_{\text {ST. }}$.

To determine which source of variance (geographic or temporal) impacts population structure, this thesis examined spatial gene flow over large and small scales in space then examined temporal variance in samples over 6 non-consecutive years (Table 2). A series of AMOVA comparisons were conducted with the goal of contrasting variances among the sampling units to determine which was greater - temporal or spatial variance. 
Table 2. Regional groupings used in AMOVA. n enumerates crabs of adult (A) or megalopae (M) age class. Region (North, Central, or South) is the geographic region used in hierarchical comparisons.

\begin{tabular}{|c|c|c|c|c|c|}
\hline Site & Year & Region & $\mathbf{n}$ & Latitude & Longitude \\
\hline $\begin{array}{l}\text { Fraser Delta, } \\
\text { British Columbia }\end{array}$ & 2009 & North & $25(\mathrm{~A})$ & $49^{\circ} 4^{\prime} 59^{\prime \prime} \mathrm{N}$ & $123^{\circ} 14 ' 39 " \mathrm{~W}$ \\
\hline $\begin{array}{l}\text { Dungeness Bay, } \\
\text { Washington }\end{array}$ & 2009 & North & $24(\mathrm{~A})$ & $48^{\circ} 9^{\prime} 41^{\prime \prime} \mathrm{N}$ & $123^{\circ} 7 ' 32 " \mathrm{~W}$ \\
\hline $\begin{array}{l}\text { Gray's Harbor, } \\
\text { Washington }\end{array}$ & 2009 & North & $25(\mathrm{~A})$ & $46^{\circ} 55^{\prime} 10^{\prime \prime} \mathrm{N}$ & $124^{\circ} 6^{\prime} 41^{\prime \prime} \mathrm{W}$ \\
\hline Ilwaco, Washington & 2009 & North & $25(\mathrm{~A})$ & $46^{\circ} 17^{\prime} 60 " \mathrm{~N}$ & $124^{\circ} 2^{\prime} 27^{\prime \prime} \mathrm{W}$ \\
\hline Astoria, Oregon & 2004 & Central & $24(\mathrm{~A})$ & $47^{\circ} 06^{\prime} 00^{\prime \prime} \mathrm{N}$ & $124^{\circ} 20^{\prime} 00^{\prime \prime} \mathrm{W}$ \\
\hline Eureka, California & 2005 & South & $25(\mathrm{~A})$ & $40^{\circ} 47^{\prime} 00^{\circ}{ }^{\circ} \mathrm{N}$ & $124^{\circ} 13^{\prime} 00^{\prime \prime} \mathrm{W}$ \\
\hline $\begin{array}{l}\text { San Francisco, } \\
\text { California }\end{array}$ & 2005 & South & $53(\mathrm{~A})$ & $37^{\circ} 27^{\prime} 00 ” \mathrm{~N}$ & $122^{\circ} 34^{\prime} 00^{\prime} \mathrm{W}$ \\
\hline $\begin{array}{l}\text { Half Moon Bay, } \\
\text { California }\end{array}$ & 2005 & South & $36(\mathrm{~A})$ & $37^{\circ} 29^{\prime} 00^{\prime \prime} \mathrm{N}$ & $122^{\circ} 29 ' 07$ 'W \\
\hline $\begin{array}{l}\text { Moss Landing, } \\
\text { California }\end{array}$ & 2005 & South & $30(\mathrm{~A})$ & $36^{\circ} 48^{\prime} 00^{\prime \prime} \mathrm{N}$ & $121^{\circ} 47^{\prime} 00^{\prime \prime W}$ \\
\hline $\begin{array}{l}\text { Port San Luis, } \\
\text { California }\end{array}$ & 2005 & South & $29(\mathrm{~A})$ & $35^{\circ} 80^{\prime} 00^{\prime} \mathrm{N}$ & $120^{\circ} 44^{\prime} 00^{\prime \prime} \mathrm{W}$ \\
\hline Coos Bay, Oregon & 2001 & Central & $135(\mathrm{M})$ & $43^{\circ} 20^{\prime} 12^{\prime \prime} \mathrm{N}$ & $124^{\circ} 19^{\prime} 14^{\prime \prime} \mathrm{W}$ \\
\hline Coos Bay, Oregon & 2003 & Central & $60(\mathrm{M})$ & $43^{\circ} 20^{\prime} 12^{\prime \prime} \mathrm{N}$ & $124^{\circ} 19^{\prime} 14^{\prime \prime} \mathrm{W}$ \\
\hline Coos Bay, Oregon & 2008 & Central & 169(M) & 4320’12”N & $124^{\circ} 19^{\prime} 14^{\prime \prime} \mathrm{W}$ \\
\hline Coos Bay, Oregon & 2009 & Central & 33(M) & $43^{\circ} 20^{\prime} 12^{\prime \prime N}$ & $124^{\circ} 19^{\prime} 14^{\prime \prime W}$ \\
\hline
\end{tabular}




\section{Tests for spatial differentiation: Exact and Mantel tests}

An Exact test (Raymond \& Rousset 1995) was preformed to test for non-random distribution of haplotypes into population samples under the hypothesis of panmixia. Arlequin 3.5 haplotypic matrices tables were used to compare all pairs of data from the complete data set of 296 adults and 406 megalopae. Sample haplotypic data table was built using 10,000 random sample haplotype frequencies from the data set (Raymond \& Rousset 1995). Observed and sampled haplotypic tables are compared for significance following the procedure. A significant score indicates that data is not randomly distributed, which may indicate differentiation across the range of $C$. magister.

A Mantel test (Mantel 1967) was conducted using Arlequin 3.5 to determine if there was a relationship between geographic distance and genetic differentiation. The first matrix consisted of geographic distance $(\mathrm{km})$ between each pair of sample sites. The second matrix consisted of the pairwise $F_{\mathrm{ST}}$ differentiation between COI sequences between all possible pairs of sites. The test of data significance used 10,000 permutations. A significant correlation between geographic distance and differentiation among the COI sequences would indicate Isolation-by-Distance, whereas a non-significant correlation would indicate that propagules were mixed across the geographic range.

\section{Marine environment variables}

In addition to considering the effect of spatial distance among populations, the present study attempted to assess whether patterns in haplotype frequency were associated with fine-scale habitat geometric or environmental variables. The relationship 
between simple genetic diversity of population samples (measured as $h$ or $\pi$ and other more complex measures including $D$ and $F_{\mathrm{S}}$ and pairwise $F_{\mathrm{ST}}$ ) was considered in correlation-based analyses with hydrological measurements including commercial catch numbers for the sampled years.

Length and width of embayment openings were measured using Google Earth 6.1 at an altitude of $100 \mathrm{~km}$. The length and the width (LxW) of entry distances into embayments (a term used in the U.S. Bureau of the Census 1990 report) were measured. The span across the waterway from an outside source of water flow was calculated as length while the width was measured as a perpendicular line towards the coastline (see Figure 2). The LxW measurement procedure is shown in Figure 2A and 2B. 

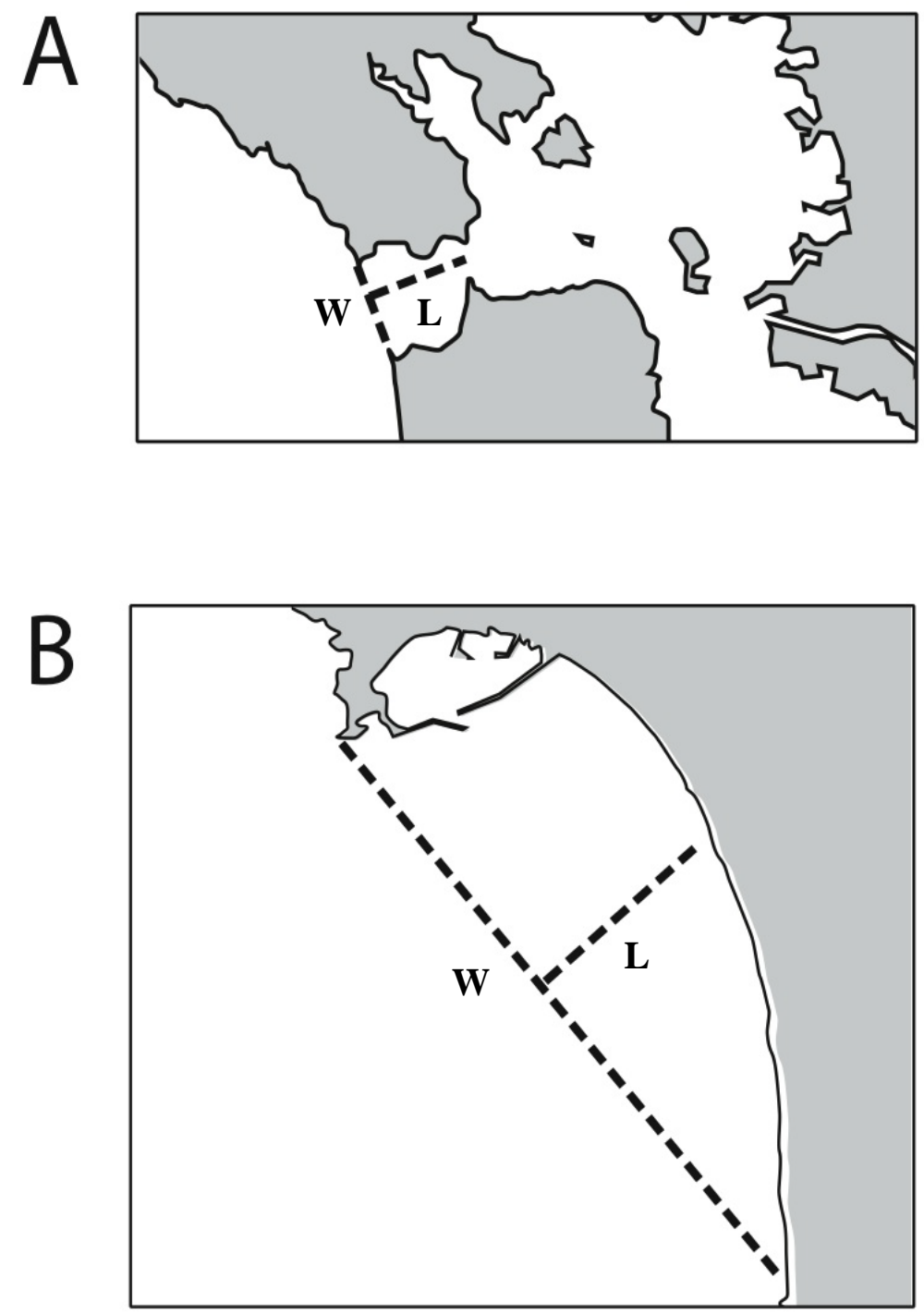

Figure 2. Schematic of embayments, showing a description of how bay opening areas by length $\mathrm{x}$ width measurements, were made (image is not to scale). A closure line was drawn from the headlands of embayments (at the western most points, in these cases). A line perpendicular to this length line was then extended to an inner edge of the inlet area as the width line. In the case of embayments that have narrow openings, such as San Francisco Bay (A) or Humboldt Bay (not shown), the perpendicular lines were extended to approximately the end of the inlet channel, as shown in (A). In the case of open-crescent shaped bays such as Half Moon Bay (B), the perpendicular line was extended to the coast. Accordingly, the bay area measurement approximates in $\mathrm{km}^{2}$ the entryway that has unhindered contact with the open ocean. 
The bay width line was extended to either the point at which the opening expands, in the case of enclosed structures, or to the point of the beach line, in the case of crescent shaped (or opening size of) bays. For example, measurement of opening size applied to the San Francisco Bay would extend from a closure line west of the Golden Gate Bridge eastwards to the shoreline to the narrowest point before the channel opens up into the SF bay, at which point, the water becomes classified as inland delta water (Figure 2A). As an example of an open-crescent shaped bay, the LxW measurement scheme used to define Half Moon Bay is shown in Figure 2B. The LxW measures approximate (in $\mathrm{km}^{2}$ ) the water domain that has unhindered contact with the open ocean and tabulated in Table 8. We confirmed that adult crabs providing data corresponding to bays were caught near $(<2 \mathrm{~km})$ these embayments though a precise location was not possible to determine as explained above.

Mean depth (m) of embayments (Table 8) were collected from National Oceanic and Atmospheric Administration (NOAA) charts available online.

The average yearly commercial catch where available was reported (in tons [equivalent to 2,000 pounds] Table 8). Measurements were found online at state reported commercial catch numbers, which correspond to the years adult crabs were sampled. We expected that high catch areas may show different diversity from low catch areas, and plotted typical seasonal tonnage data with genetic diversity measures. All Dungeness crab fisheries are managed primarily by a minimum size limit and non-retention of females (Yonis 2010). For Fraser Delta, crab catch was reported by DFO (Department of 
Fisheries and Oceans Canada) for 2009 and available online. Data for Washington State combined Dungeness crab, including Grays Harbor and Ilwaco, was reported for the 2009 season by Washington Department of Fish and Wildlife (WDFW) and available online (WDFW 2013). For California Dungeness crabs in the Northern region, which includes Half Moon Bay and San Francisco, catch data was reported by California Department of Fish and Wildlife (DFW) and included catch for Eureka Bay and Fort Bragg available online (DFW 2013). California’s Department of Fish and Wildlife reported commercial fishery catch for Dungeness crab as two main sections along the coastline: Northern California and Southern California (DFW 2013). Southern California fishing areas include other site such as Avila-Morro Bay, Monterey bay, while the Northern area group San Francisco with Bodega Bay. The Morro Bay and Monterey fisheries are minor compared to the Northern San Francisco-Bodega Bay fisheries. The commercial catch regulations require throwing back of females (Department of Fish and Wildlife 2013, Washington Department of Fish and Wildlife 2013). There were no distinction among sampled sites of Half Moon Bay and San Francisco. Similarly, Southern California catch, which included Moss Landing and San Luis Obispo did not distinguish among coast sites and data is grouped with other Southern California coastal cities (DFW 2013).

Turbidity of embayments for each location was approximated using Nephelometric Turbidity Units (NTU) and data were collected from various published papers (Table 8). NTU is a measure of waterborne light-scattering particles when a light beam is focused through water and reflected back to a detector. The resulting light scatter can be used as a measure of turbidity. In this study, turbidity data as NTUs were 
obtained from published records that were made using calibrated a nephelometer (Myre \& Shaw 2006). Other studies have shown that NTU in many cases approximates the flow of water through embayments (White 1994). Turbidity and total solids may also increase sharply during and immediately following a rainfall, a temperature increase (which results in oxygen-concentration decrease), or response to toxin levels (EPA 2009). As one example, a study found that agricultural field runoff in its watershed contributed about 22,500 tons of sediment per year to Weeks Bay, in Alabama (EPA 2009).

Averaged current velocity $\left(\mathrm{cm}^{3} / \mathrm{s}\right)$ data were utilized from each site to approximate the flow of water in and out of embayments (Table 8). Velocity data were obtained from acoustic Doppler systems of the publically accessible National Oceanic and Atmospheric Administration (NOAA) National Data Bouy Center (NDBC) database. Average velocity was determined as the current speed collected from a single surface buoy over 24 hour period, quality-controlled, and reported to the website.

We correlated matrices of pairwise $F_{\mathrm{ST}}$ measures of adult samples from Results section (Table 5A) with embayment opening size measurements (Table 8) as well as with $D$ and $F_{\mathrm{S}}$ measures (Table 3A) to examine whether hydrology correlated to population diversity.

\section{Examination of the association between genetic and environmental variables}

Canonical correlation analysis (CCA) was used to determine if there was a relationship between a suite of environmental measures and a suite of genetic diversity measures. The environmental measures included opening size, mean depth, NTU, and 
velocity in Table 8 . The genetic measures included $h$ and $\pi$ as well as neutrality scores $D$ and $F_{\mathrm{S}}$ (Table 3A and 3B). Canonical loadings, correlations between the variables and the canonical scores for the suite of variables being measures, were used to interpret the canonical scores. Positive loading indicates that small values of canonical score correspond to small values of the variable, whereas a negative loading indicates that small values of canonical scores correspond to the high values of the variable.

Canonical correlation analysis requires a linear relationship between variables: therefore, prior to testing, we plotted all possible relationships among genetic variables ( $h$ and $\pi$ ) and neutrality scores ( $F_{\mathrm{S}}$ and $D$ ) with environmental variables (LxW, mean depth, NTU, and velocity) to verify these were linear. The Pearson test for independence revealed that gene diversity $(h)$ and nucleotide diversity $(\pi)$ were not independent and could be used interchangeably. Similarly, $F_{\mathrm{S}}$ and $D$ were not independent and could be used interchangeably for correlation tests. The correlation test was a novel approach to analyzing genetic diversity spatial patterns using easily obtained environmental variables.

Pairwise $F_{\mathrm{ST}}$ and LxW scores were compared to determine if a relationship existed (Results section: Figure 6). To further explain any findings of correlation or genetic difference, as pairwise $F_{\text {ST }}$ scores, and the highest correlated physical data (which was preliminarily opening $\mathrm{LxW}$ ) were cross compared using Robust Linear Regression of observed data. The Shapiro-Wilk test indicated data was normally distributed and also provided a test for significance among data sets. This regression method was designed to not be overly affected by violations of assumptions in the underlying data-generating 
process. In contrast, the least squares estimates for regression models might have proved too robust (might have given too much weight) to data outliers (Wilcox 1998).

The Wilcoxon-signed rank test (1945) was preformed to compare pairwise $F_{\text {ST }}$ extracted from the population matrix to the environmental variables for given populations in order to determine if data sets follow normal distribution to avoid a false positive result. Helping to avoid a false positive result, nonparametric (the Wilcoxon test being an example) tests do not assume that the data conform to a particular probability distribution. The Wilcoxon test gives the value $Z$, the sum of signed ranks divided by square root times the sum of squared ranks (Wilcoxon 1945). A p-value is accepted if a probability test calculates that observed data is less then a statistically derived estimate of data level of $\mathrm{p} \leq 0.05$.

\section{RESULTS}

\section{Molecular diversity}

Comparison of COI sequences of 359 base pairs from 296 C. magister adults yielded 55 polymorphic sites and 86 haplotypes (Table 3A). There was a ratio of 34 transitions to 23 transversions and a total of 57 substitutions. The three most common haplotypes in the adult data set occurred at frequencies of $29.0 \%(n=86), 21.9 \%(n=65)$, and $8.4 \%(n=25)$. No other haplotypes occurred at frequencies greater than $2 \%(k=6)$, and the proportion of singleton (Slatkin 1985) sequences occurring once in the data set was $40.5 \%(n=120)$. 
Table 3A. C. magister adult diversity statistics. Significant $(\mathrm{p}<0.05)$ test results are shown in bold; $* \mathrm{p} \leq 0.01 ; * * \mathrm{p} \leq 0.001$.

\begin{tabular}{|c|c|c|c|c|c|c|}
\hline $\begin{array}{l}\text { Population, } \\
\text { (abbrev.), } \\
\text { collection date }\end{array}$ & $n$ & $\begin{array}{c}\text { Number of } \\
\text { private } \\
\text { Haplotypes } \\
(k)\end{array}$ & $\begin{array}{c}\text { Gene } \\
\text { Diversity } \\
\text { (h) }\end{array}$ & $\begin{array}{c}\text { Nucleotide } \\
\text { Diversity } \\
(\pi)\end{array}$ & $\begin{array}{c}\text { Tajima's } \\
D\end{array}$ & $\begin{array}{c}\text { Fu's } \\
F_{S}\end{array}$ \\
\hline $\begin{array}{l}\text { Fraser Delta } \\
\text { (FD) } 2009\end{array}$ & 25 & 8 & 0.630 & 0.003 & -1.720 & $-3.902 *$ \\
\hline $\begin{array}{l}\text { Dungeness Bay } \\
\text { (DB) } 2009\end{array}$ & 24 & 9 & 0.866 & 0.008 & 0.905 & -1.541 \\
\hline $\begin{array}{l}\text { Gray's Harbor } \\
\text { (GH) } 2009\end{array}$ & 25 & 9 & 0.823 & 0.007 & -0.227 & -2.295 \\
\hline $\begin{array}{c}\text { Ilwaco } \\
\text { (IW) } 2009\end{array}$ & 25 & 9 & 0.817 & 0.004 & -0.868 & $-4.435^{* *}$ \\
\hline $\begin{array}{c}\text { Astoria } \\
\text { (AS) } 2004\end{array}$ & 24 & 22 & 0.981 & 0.014 & -1.007 & $-19.629 * *$ \\
\hline $\begin{array}{c}\text { Eureka } \\
\text { (EK) } 2005\end{array}$ & 25 & 14 & 0.947 & 0.008 & -0.589 & $-7.550 * *$ \\
\hline $\begin{array}{l}\text { Half Moon Bay } \\
\text { (HM) } 2005\end{array}$ & 36 & 12 & 0.789 & 0.005 & -1.322 & $-6.540 * *$ \\
\hline $\begin{array}{l}\text { San Francisco } \\
\text { (SF) } 2005\end{array}$ & 53 & 18 & 0.837 & 0.006 & $-1.875^{*}$ & $-10.507 * *$ \\
\hline $\begin{array}{l}\text { Moss Landing } \\
\text { (ML) } 2005\end{array}$ & 30 & 12 & 0.862 & 0.006 & -1.183 & $-5.728 * *$ \\
\hline $\begin{array}{l}\text { Port San Luis } \\
\text { (SL) } 2005\end{array}$ & 29 & 14 & 0.857 & 0.005 & -1.777 & $-10.139 * *$ \\
\hline Total adults & 296 & 90 & 0.851 & 0.007 & $-2.145^{* *}$ & $-26.733^{* *}$ \\
\hline
\end{tabular}

Adults sharing haplotypes at one or more polymorphic sites constituted $68 \%$ of the population overall, while private haplotypes not shared with any other population constituted 32\%. There was a ratio of 85 transitions to 48 transversions and a total of 133 substitutions. There were six synonymous changes in the first codon, and the remaining 42 synonymous changes (silent substitutions) were in the $3^{\text {rd }}$ codon position. 
Truncating the 2001, 2003, 2008, and 2009 megalopae dataset in order to include the 222 base pairs common with the previous megalopae dataset studies (Dedhia 2005, Lardy 2006) yielded 28 unique haplotypes (Table 3B). Truncation was necessary in order to ascertain the most precise reading of some sequences from previous megalopae datasets (2001 and 2003). The three most common haplotypes in the larval data set, which were the same three common haplotypes in the adult set, occurred at frequencies of $23.9 \%$ for haplotype $1(n=97), 24.9 \%$ for haplotype $2(n=101)$, and $8.62 \%(n=35)$.

Table 3B. C. magister megalopae diversity statistics, pooling larvae collected in 2001, 2003, 2008, and 2009 at Coos Bay. Significant $(\mathrm{p}<0.05)$ test results are shown in bold; $* \mathrm{p} \leq 0.01$.

\begin{tabular}{|c|c|c|c|c|c|c|}
\hline Collection year & $n$ & $\begin{array}{c}\text { Number of } \\
\text { private } \\
\text { Haplotypes } \\
(k)\end{array}$ & $\begin{array}{c}\text { Gene } \\
\text { Diversity } \\
\text { (h) }\end{array}$ & $\begin{array}{c}\text { Nucleotide } \\
\text { Diversity } \\
(\pi)\end{array}$ & $\begin{array}{c}\text { Tajima's } \\
D \\
\end{array}$ & $\begin{array}{c}\text { Fu's } \\
F_{S} \\
\end{array}$ \\
\hline Coos Bay 2001 & 135 & 4 & 0.583 & 0.006 & 1.385 & 2.580 \\
\hline Coos Bay 2003 & 75 & 8 & 0.801 & 0.016 & 0.887 & 2.572 \\
\hline Coos Bay 2008 & 165 & 14 & 0.680 & 0.004 & -1.361 & $-8.109 *$ \\
\hline Coos Bay 2009 & 31 & 11 & 0.821 & 0.014 & -1.697 & -2.226 \\
\hline Total megalopae & 406 & 28 & 0.829 & 0.010 & -0.197 & -1.296 \\
\hline
\end{tabular}


Some larval samples had little or no diversity (Table 4). For example, only one haplotype was found in the light trap (which was deployed continuously since April 2001 and checked daily) for the July and September 2001 samples. When multiple weeks samples from 2008 and 2009 were considered (each week having sample-sizes of 8 to 81 megalopae per trap event) only two haplotypes were found in August 2008. The remaining sampled weeks had only one haplotype from April 2008 until August 2009 (see Table 4). The haplotypes tended to be common haplotypes (haplotype assigned number 1 , 2, or 3 ), suggesting very few females contributed to the total brood population from Coos Bay. Exact contribution of females, in terms of numbers, would require use of a more variable class of genetic markers or more loci. 
Table 4. Distribution of haplotypes found in megalopae populations. Megalopae were collected by light trap in Coos Bay, OR. Dr Alan Shanks oversaw collections.

\begin{tabular}{|c|c|c|c|c|}
\hline Period & $\begin{array}{l}\text { Approximate } \\
\text { collection } \\
\text { period (days) }\end{array}$ & $\begin{array}{c}\text { Number of } \\
\text { individuals } \\
\text { analyzed }\end{array}$ & $\begin{array}{l}\text { Number of } \\
\text { haplotypes }\end{array}$ & $\begin{array}{c}\text { Actual haplotypes } \\
\text { present and } \\
\text { frequencies (n) }\end{array}$ \\
\hline July Wk4 2001 & $7+$ & 12 & 1 & $5(12)$ \\
\hline Aug Wk1 2001 & 7 & 14 & 1 & $3(14)$ \\
\hline Aug Wk2 2001 & 7 & 28 & 1 & $1(28)$ \\
\hline Sept Wk2 2001 & $7+$ & 81 & 1 & $6(81)$ \\
\hline Jun Wk2 2003 & $7+$ & 9 & 1 & $1(9)$ \\
\hline \multirow[t]{3}{*}{ Jun Wk4 2003} & 14 & 24 & 2 & $1(1)$ \\
\hline & & & & $7(23)$ \\
\hline & & & & $14(1)$ \\
\hline \multirow[t]{2}{*}{ Jul Wk1 2003} & 7 & 21 & 2 & $8(20)$ \\
\hline & & & & $9(1)$ \\
\hline \multirow[t]{2}{*}{ Jul Wk2 2003} & 7 & 6 & 2 & $10(5)$ \\
\hline & & & & $11(1)$ \\
\hline \multirow[t]{2}{*}{ Jul Wk3 2003} & 21 & 15 & 2 & 2(14) \\
\hline & & & & $15(2)$ \\
\hline Aug Wk1 2003 & 14 & 17 & 1 & $12(12)$ \\
\hline \multirow[t]{3}{*}{ Aug Wk2 2003} & 7 & 10 & 3 & $9(1)$ \\
\hline & & & & $13(8)$ \\
\hline & & & & $14(1)$ \\
\hline Apr Wk4 2008 & 7 & 8 & 1 & $1(8)$ \\
\hline May Wk2 2008 & 14 & 8 & 1 & $1(8)$ \\
\hline May Wk3 2008 & 7 & 12 & 1 & $2(12)$ \\
\hline May Wk4 2008 & 7 & 11 & 1 & $2(11)$ \\
\hline Jun Wk2 2008 & 14 & 11 & 1 & $2(11)$ \\
\hline Jun Wk3 2008 & 7 & 12 & 1 & $2(12)$ \\
\hline Jun Wk4 2008 & 7 & 12 & 1 & $1(12)$ \\
\hline Jul Wk1 2008 & 7 & 11 & 1 & $2(11)$ \\
\hline Jul Wk2 2008 & 7 & 10 & 1 & $1(10)$ \\
\hline Jul Wk3 2008 & 7 & 12 & 1 & $1(12)$ \\
\hline Jul Wk4 2008 & 7 & 12 & 1 & $1(12)$ \\
\hline Aug Wk2 2008 & 14 & 10 & 1 & $2(10)$ \\
\hline \multirow[t]{2}{*}{ Aug Wk3 2008} & 7 & 12 & 2 & $1(11)$ \\
\hline & & & & $2(1)$ \\
\hline Aug Wk4 2008 & 7 & 12 & 1 & $1(12)$ \\
\hline Sep Wk1 2008 & 7 & 12 & 1 & $3(12)$ \\
\hline Apr Wk4 2009 & 7 & 10 & 1 & $3(10)$ \\
\hline $\begin{array}{l}\text { Jul Wk2 } 2009 \\
\text { Aug Wk4 } 2009\end{array}$ & $\begin{array}{l}7 \\
7\end{array}$ & $\begin{array}{l}10 \\
11\end{array}$ & $\begin{array}{l}1 \\
1\end{array}$ & $\begin{array}{l}1(10) \\
4(11)\end{array}$ \\
\hline
\end{tabular}




\section{Population diversity}

Nucleotide diversity $(\pi)$ and gene diversity $(h)$ of all sampled adults were similar to larval population total sampled diversity scores (Table 3A and 3B). Nucleotide and gene diversity for the entire adult dataset were 0.010 and 0.850 (Table 3A). For larvae from Coos Bay sampled over the years, $(\pi)$ and $(h)$ diversities had a net average of 0.010 and 0.829 (Table 3B).

Megalopae samples collected in 2001 and in 2008 had lower diversity on average than adults: for $2001 \pi=0.006, h=0.583$; for $2008 \pi=0.005, h=0.680$ (Table 3B). Megalopae sampled from 2003 and 2009 had higher diversity: for $2003 \pi=0.016, h=$ 0.801 ; for $2009 \pi=0.014, h=0.821$ (Table 3B), which were in the range of those generally seen in adult populations (Table 3A). Assessed over the time frame of a year cohorts of megalopae from Coos Bay, varied in diversity, $h$ ranged from 0.63 to 0.98 and their nucleotide diversity, $\pi$ ranged from 0.003 to 0.014 (Table 3B). When larvae were broken down by one-week time frames (Table 4) single haplotypes appeared over approximately 7 or more days of sampling, the repeated appearance of single haplotypes suggesting broods of larvae were collected together.

Figure 3 illustrates the diversity of adult populations in relation to their geographic distribution and embayment dimensions. As seen in the insert, narrow mouthed embayments had higher haplotypic diversity generally. Typically, three common haplotypes were found in each location (Figure 3). 


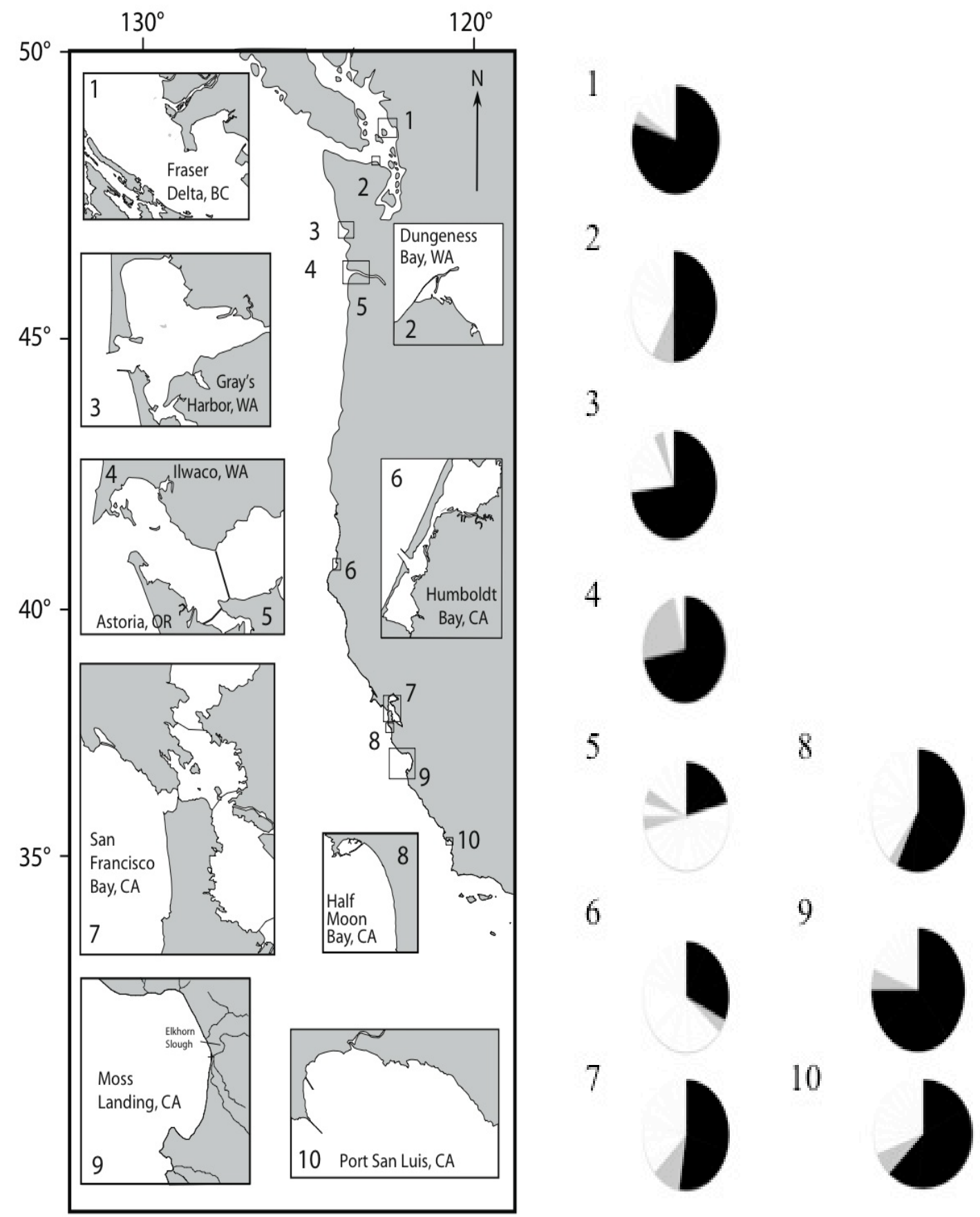

Figure 3. Diversity pie charts and collection inserts of embayments. Black chart segments represent frequencies of haplotypes found at all sites, grey indicates haplotypes shared at one or more sites, and white indicates private haplotypes found only at one site. 
The black shading in pie charts (Figure 3) are shared haplotypes throughout the Dungeness crab's range, whereas grey shading represents haplotypes shared in one or more locations but not in all populations, and white portions are private haplotypes unique to that embayment. Throughout the Northern American Pacific range, each population site shares haplotypes 1, 2, and/or 3. As Figure 3 indicates, narrow mouthed bays like Dungeness Bay and Humboldt Bay have over 50\% of private haplotypes, suggesting areas of high genetic diversity.

There are notable anomalies. At Astoria where over 50\% are a private haplotype, but one $\mathrm{km}$ north on the same river is Ilwaco over $90 \%$ are shared geographically. Populations at San Francisco, Half Moon Bay, Moss Landing, and the port of San Luis Obispo have $50 \%$ or more shared haplotypes, which corresponds to the lack of regional differentiation found in the pairwise $F_{\text {ST }}$ scores and AMOVA results. There was one notable exception to net diversity scores in the San Francisco population. In the San Francisco population ( $\mathrm{n}=53$ ), haplotype 2 was absent, though haplotype 2 appeared in all other populations.

\section{Neutrality test results}

Tajima's $D$ in adult population samples was generally negative in value, but only three of the ten populations showed statistically significant deviations from the neutral model (Table 3A). The remaining seven adult populations had non-significant p-values. Tajima’s $D$ was estimated in four larval samples from years of collections in Coos Bay 
(Table 3B); two years had positive $D$ values (2001 and 2003), and two negative $D$ values (2008, 2009), and only one adult population was statistically significant (2009). A broad survey of 21 ssp. of crustaceans suggests slightly negative $D$ is the most common pattern (Kelly \& Palumbi 2010).

As suggested earlier, $F_{\mathrm{S}}$ scores are particularly sensitive to detecting data sets that have a "star phylogeny" and the large numbers of alleles may indicate an historic population expansion (Fu 1997). In the sampled adult populations, $F_{\mathrm{S}}$ values were slightly negative, and all populations were statistically significant with two exceptions: Dungeness Bay $\left(F_{\mathrm{S}}=-1.540, \mathrm{p}=0.212\right)$ and Gray's Harbor $\left(F_{\mathrm{S}}=-2.295, \mathrm{p}=0.098\right)$. Megalopae samples from Coos Bay (Table 3B) had two nominally negative $F_{\mathrm{S}}$ scores (2008 and 2009) but only one statistically significant score (negative $F_{S}$ in 2008).

There was no obvious relationship in comparing neutrality scores and numbers of private haplotypes, which ranged from 8 to 22 private haplotypes in adult samples (Table 3A) and 4 to 14 in the megalopae sampled over several years at Coos Bay (Table 3B).

The mismatch distribution of both the adult and larval populations sets was a unimodular, smooth wave (Figure 4A, Figure 4B). The least squares test of the fit with the Sudden Expansion model (Schneider \& Excoffier 1999) was non-significant, indicating distributions agree with a history of recent population expansion: for adults, the mean Sum of Squares deviations (SSD) was 0.008, $\mathrm{p}=0.469$, and for for larvae SSD was 0.049, $\mathrm{p}=0.068$. Harpending's raggedness index for the total adult populations set was $r=$ 0.062, $\mathrm{p}=0.458$, and for the larvae populations was $r=0.172, \mathrm{p}=0.051$. 


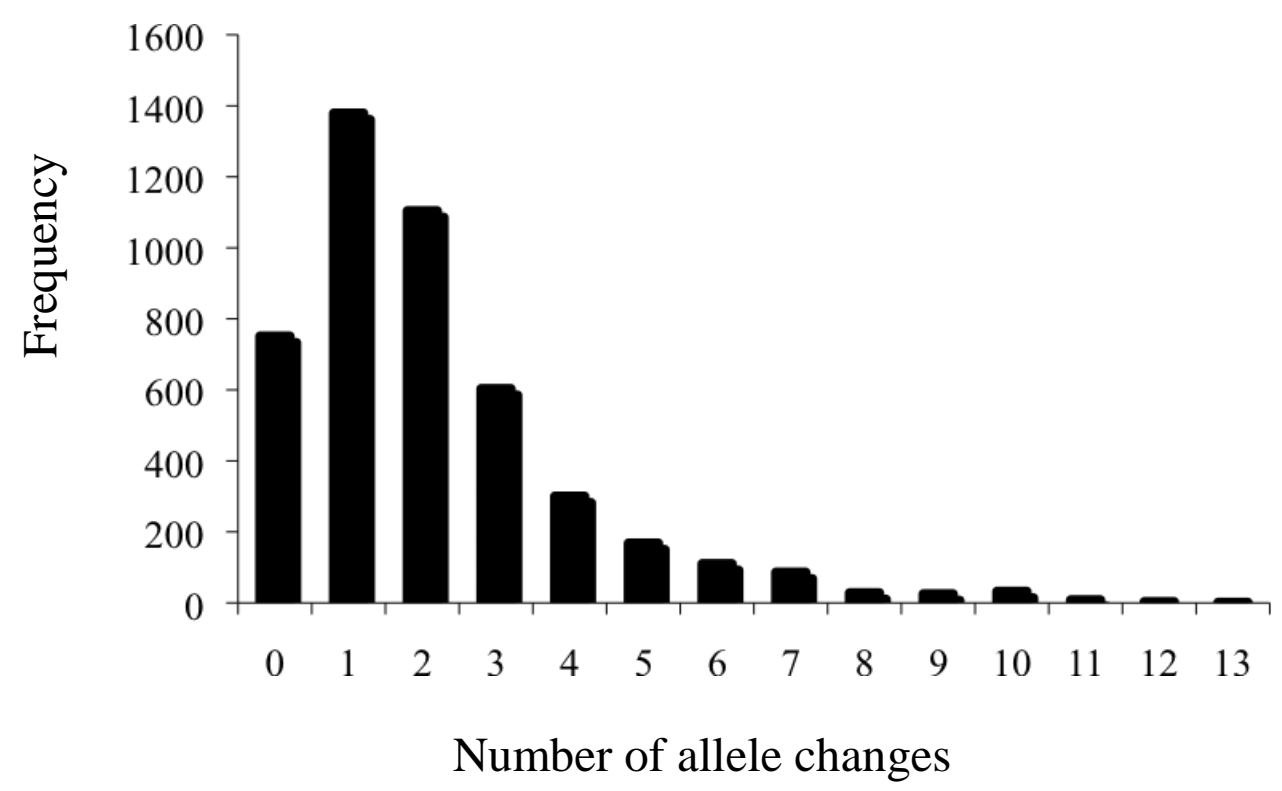

Figure 4A. The mismatch distribution of COI sequences obtained from adult populations. The mean tau value of allele changes was 2.253.

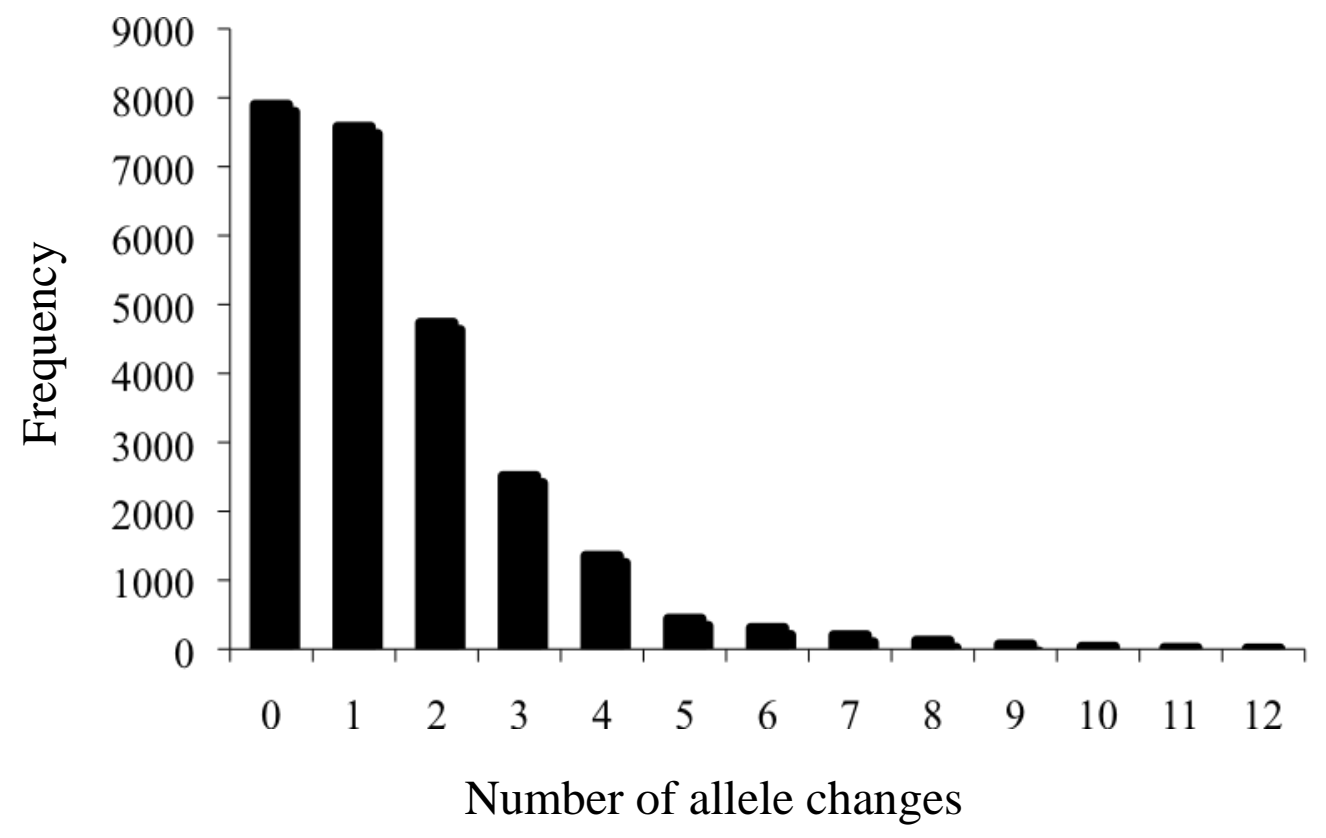

Figure 4B. The mismatch distribution of COI sequences obtained from larvae populations. The bar graph illustrated the uni-modal wave distribution of allele changes in COI sequences. The mean tau value of allele changes was 2.565 . 
In the adults, the lack of significance of the Harpending’s raggedness index also supported the sudden expansion effect. Notably, there were more that more instances of the same haplotype (number of differences among sequences $=0$ ) in larval populations (discussed below) which may have contributed to the raggedness of the larval mismatch. It is also possible that the lower number of sites used in larval comparisons influenced the mismatch shape.

Adult and larval expansion estimates indicated the time since expansion having an older interval in the larval population sample, using the formula $\tau=2 u t$ and mutation rate $(\mu)$ of $2.3 \%$ per million years.

Using the adult sequences of $359 \mathrm{bp}$, the mean $\tau$ for 10 populations was 2.253, (95\% confidence interval: $1.200-3.208$ ); and $\theta_{0}<0.001$; and $\theta_{1}=70038.443$; where $\theta_{0}$ is the mutation parameter estimate and $\theta_{1}$ the expansion under an infinite allele model of mutation (Rogers 1995). In this case, $t$ was estimated at $0.242 \mathrm{MY}$ (CI: $0.145-0.389$ MY). The median estimate of $t$ using the larval sample (222 bp) was $0.502 \mathrm{MY}(\tau=$ 2.565, and the 95\% confidence interval ranged from 1.068 to $4.889 \mathrm{MY}$ ). The larval mismatch distribution variance had a higher upper limit $(t=0.209-0.976 \mathrm{MY})$ than the adult population mismatch. Sample larvae represent the general population pool and look to have a larger $\mathrm{N}_{\mathrm{e}}$ if tau $(\tau=2.565)$ is higher. 


\section{Population structure}

Pairwise $F_{\text {ST }}$ tests and AMOVA indicated no regional structure, but local spatial difference was seen in the comparison of some adult populations. Comparison of megalopae collections over different times revealed varying relative haplotype frequency, which suggests local variance is due to reproductive success rather than regional dispersal.

\section{Population structure analysis considering adults}

While there was no indication of large-scale regional differentiation, adult populations showed small-scale regional differentiation (Table 5A). The overall adult pairwise $F_{\text {ST }}$ considering 10 populations was 0.090 , p $<0.001 .64 \%$ of the adult pairwise $F_{\text {ST }}$ comparisons (23 out of the 36 in Table 4A) were statistically significant $(\mathrm{p}<0.05)$. Three adult populations - Dungeness Bay, Astoria, and Eureka - had significantly high pairwise $F_{\text {ST }}\left(\right.$ all $F_{\text {ST }}$ scores were below p $<0.01$ ) as compared to all other populations.

Table 5A. A pairwise $F_{\mathrm{ST}}$ matrix for adult $C$. magister populations. Label abbreviation and dates correspond to Table 3.A. Bold indicates $\mathrm{p}$-values of $\leq 0.05$; * indicates $\mathrm{p} \leq$ $0.01 ; * *$ indicates $\mathrm{p} \leq 0.001$.

\begin{tabular}{|c|c|c|c|c|c|c|c|c|c|}
\hline DB2009 & - & & & & & & & & \\
\hline GH2009 & 0.108 & - & & & & & & & \\
\hline IW2009 & $0.177^{* *}$ & 0.043 & - & & & & & & \\
\hline AS2004 & $0.198^{* *}$ & $0.122 * *$ & 0.068* & - & & & & & \\
\hline EK2005 & 0.119* & 0.085* & $0.158 * *$ & $0.171 * *$ & - & & & & \\
\hline SF2005 & $0.175^{* *}$ & 0.077* & 0.021 & $0.069 * *$ & $0.121^{* *}$ & - & & & \\
\hline HB2005 & $0.205^{* *}$ & 0.090 & -0.010 & $0.081 * *$ & $0.174 * *$ & 0.029 & - & & \\
\hline ML2005 & $0.149 * *$ & 0.052 & -0.003 & $0.088 * *$ & $0.130 * *$ & 0.032 & 0.003 & - & \\
\hline SL2005 & $0.211^{* *}$ & 0.056 & -0.003 & $0.088 * *$ & $0.157^{* *}$ & 0.021 & 0.017 & 0.022 & - \\
\hline FD2009 & $0.194 * *$ & $0.129 * *$ & 0.018 & 0.068* & $0.175^{* *}$ & 0.013 & -0.008 & -0.015 & 0.040 \\
\hline
\end{tabular}


The Mantel and the Exact tests supported AMOVA inference, revealing no structure throughout the range in adult samples. The Mantel test correlating the adult pairwise $F_{\text {ST }}$ scores and geographic distance among sites was non significant $(r=0.059 \mathrm{p}$ $=0.289$ ). The Exact test also could not reject the null hypothesis of a non-random distribution of haplotypes among the samples from along C. magister's range $(\mathrm{p}=0.45)$.

Population structure analysis sampling megalopae.

The mean pairwise $F_{\mathrm{ST}}$ for the total megalopae population was $0.387(\mathrm{p}<0.001)$ and ranging from 0.037 to 0.510 . The lowest pairwise $F_{\text {ST }}$ value was between years 2008 and 2009 (Table 5B). The highest difference was between 2001 and 2008 (Table 5B).

Table 5B. A pairwise $F_{\text {ST }}$ matrix for megalopae populations from Coos Bay, OR. Label abbreviation and dates correspond to Table 3.B. Bold indicates p-values of $\leq 0.05$; * indicates $\mathrm{p} \leq 0.01 ; * *$ indicates $\mathrm{p} \leq 0.001$.

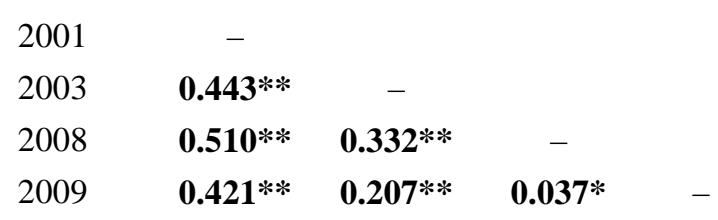

Larval samples were grouped by annual collection time for analysis. Data samples compared pairs of years larvae were collected for the pairwise $F_{\mathrm{ST}}$ test (Table 5B). In addition to comparing by years, larvae were tested as separate pairs of monthly groups across each year, and also by weekly groups across years. Although data sets pooled by week and then again by month revealed significant differences, the year-toyear comparisons revealed the greatest differentiation and shown in Table 5B. 


\section{AMOVA test for regional differentiation}

Different year groups of both adult and megalopae samples had higher $\Phi_{\mathrm{ST}}$ difference more than even pairs of adult populations sampled at different geographic ends of the $3000 \mathrm{~km}$ coast line. The first AMOVA arrangement (Table 6) was conducted to test crab populations from 3 geographic regions indicated in comparison 1 and included adults and larvae, showing no evidence of regional differentiation $\left(\Phi_{\mathrm{CT}}=-0.004, \mathrm{p}=\right.$ 0.477). In comparison 2, geographic structure was not apparent across the 3 large-scale regions when adults only were considered $\left(\Phi_{\mathrm{CT}}=0.013, \mathrm{p}=0.096\right)$ (comparison 2; Table 6). Within these regions, within-group $\left(\Phi_{\mathrm{SC}}\right)$ and inter-population variance $\left(\Phi_{\mathrm{ST}}\right)$ components were significant (see comparison 2 and 3; Table 6). 
Table 6. AMOVA tests of alternative spatial and temporally based comparisons. Comparisons are listed by number for reference. P-values are given in parentheses and bold numbers emphasis significant values.

\begin{tabular}{|c|c|c|c|c|}
\hline Comparison & AMOVA test arrangement & $\begin{array}{l}\Phi_{\mathrm{CT}} \\
(\mathrm{p})\end{array}$ & $\Phi_{\mathrm{SC}}(\mathrm{p})$ & $\Phi_{\mathrm{ST}}(\mathrm{p})$ \\
\hline 1 & $\begin{array}{l}3 \text { spatial groupings of adults (North } \\
\text { FD, DB, GH, IW; Central AS, EK; } \\
\text { and South SF, HB, ML, SL) and } \\
\text { megalopae from Coos Bay. }\end{array}$ & $\begin{array}{l}-0.004 \\
(0.477)\end{array}$ & $\begin{array}{c}\mathbf{0 . 2 8 2} \\
(<0.001)\end{array}$ & $\begin{array}{c}\mathbf{0 . 2 7 4} \\
(<0.001)\end{array}$ \\
\hline 2 & $\begin{array}{l}3 \text { spatial groupings of adults only } \\
\text { (North, Central, and South). }\end{array}$ & $\begin{array}{c}0.013 \\
(0.096)\end{array}$ & $\begin{array}{c}\mathbf{0 . 0 8 1} \\
(<0.001)\end{array}$ & $\begin{array}{c}\mathbf{0 . 0 9 3} \\
(<0.001)\end{array}$ \\
\hline 3 & $\begin{array}{l}2 \text { spatial groupings of adults only } \\
\text { (North FD, DB, GH, IW, AS; South } \\
\text { EK, SF, HB, ML, SL). }\end{array}$ & $\begin{array}{l}-0.008 \\
(0.670)\end{array}$ & $\begin{array}{c}\mathbf{0 . 0 9 3} \\
(<0.001)\end{array}$ & $\begin{array}{c}\mathbf{0 . 0 8 6} \\
(<0.001)\end{array}$ \\
\hline 4 & $\begin{array}{l}6 \text { temporal groupings of adults and } \\
\text { megalopae by net year (2001, 2003, } \\
2004,2005,2008 \text {, and 2009). }\end{array}$ & $\begin{array}{c}\mathbf{0 . 2 1 2} \\
(0.037)\end{array}$ & $\begin{array}{c}\mathbf{0 . 1 0 7} \\
(<0.001)\end{array}$ & $\begin{array}{c}\mathbf{0 . 2 9 7} \\
(<0.001)\end{array}$ \\
\hline 5 & $\begin{array}{l}3 \text { temporal groupings of adults only } \\
(2004,2005 \text {, and 2009). }\end{array}$ & $\begin{array}{c}\mathbf{0 . 0 3 9} \\
(0.023)\end{array}$ & $\begin{array}{c}\mathbf{0 . 0 6 5} \\
(<0.001)\end{array}$ & $\begin{array}{c}\mathbf{0 . 1 0 2} \\
(<0.001)\end{array}$ \\
\hline 6 & $\begin{array}{l}4 \text { temporal groupings of megalopae } \\
\text { from Coos Bay arranged by month } \\
\text { 2001: June, July, August; } \\
\text { 2003: June July August; } \\
\text { 2008: April, May, June, July, } \\
\text { August, September; } \\
\text { 2009: April, July August. }\end{array}$ & $\begin{array}{c}\mathbf{0 . 1 9 7} \\
(0.035)\end{array}$ & $\begin{array}{c}\mathbf{0 . 6 1 8} \\
(<0.001)\end{array}$ & $\begin{array}{c}\mathbf{0 . 6 9 4} \\
(<0.001)\end{array}$ \\
\hline
\end{tabular}

To determine if the spatial structure occurred in a simpler North to South scale rather than 3 regions, adult populations were arranged as two broader regions (comparison 3; Table 6), These also revealed no structuring: $\Phi_{\mathrm{CT}}=-0.008, \mathrm{p}=0.670$.

\section{AMOVA based comparisons of megalopae sampled at different times}

AMOVAs were next conducted across 3 separate arrangements of adults by year, adult and larvae by year, and finally adults and larvae by month (comparison 4, 5, and 6; 
Table 6). Differentiation was often observed in comparisons of adults and larvae $\left(\Phi_{\mathrm{CT}}=\right.$ 0.212, $\mathrm{p}=0.037$, comparison 4). In comparison 4 (Table 6), megalopae from Coos Bay from the years 2001, 2003, 2008 and 2009 were compared to adults from 2004 (which included only AS), 2005 (which included SF, HB, ML, SL) and 2009 (which included FD, DB, GH, and IW). Temporal variance of megalopae and adults (comparison 4) withingroup years $\left(\Phi_{\mathrm{CT}}=0.212\right)$ was similar to comparison 1 (Table 6) spatial within-group variance $\left(\Phi_{\mathrm{SC}}=0.282\right)$.

The highest variance levels in AMOVA occurred in comparing groups of larvae only collected across multiple years (comparison 5 and 6; Table 6). The strongest variance was found in comparison 6 (Table 6) in which megalopae samples were broken down into collection months through out 2001, 2003, 2008, and 2009. An AMOVA across these 4 annual groups showed significant differences among monthly samples $\left(\Phi_{\mathrm{CT}}=0.197 \mathrm{p}=0.035\right)$ as well as within-group and within-population variance when arranged by months.

The allele frequency difference observed among concentrated groups of larvae could be a result of related larvae rafting together over 6 months as they disperse in the open ocean, completing stage I-V development. This effect may be seen in examining the frequency of private haplotypes (Table 4), as there are a low number of unique haplotypes and mostly common haplotypes are sampled together. Megalopae were lighttrap sampled through out an entire month in time periods ranging over the course of about 7 to 14 days, suggesting broods of larvae (characterized by a single private haplotype) are recruiting into estuaries together after months at sea. 


\section{Consideration of diversity measures and environmental variables}

We examined population diversity measures $(h$ or $\pi)$ to determine whether they correlate with easily obtained environmental variables. Larvae were not considered for this relationship test, having been sampled in a single location, Coos Bay, OR. Adult genetic diversity (Table 3A) and environmental variables (Table 7, 8, and 9) were tabulated and data was then tested for statistical normality. The Shapiro-Wilk (1965) test indicated that NTU was not normally distributed and was subsequently transformed with natural log for analyses as an environmental variable (Table 9). 
Table 7. Reported turbidity measurements (Nephelometric Turbidity Units, averaged) at selected sites with references cited.

\begin{tabular}{|c|c|c|c|c|c|}
\hline Area & $\begin{array}{c}\text { Average } \\
\text { turbidity } \\
\text { (NTU) } \\
\end{array}$ & $\begin{array}{l}\text { Location } \\
\text { notes }\end{array}$ & $\begin{array}{l}\text { Geographic } \\
\text { density of } \\
\text { sampling } \\
\end{array}$ & $\begin{array}{l}\text { Sampling } \\
\text { frequency }\end{array}$ & $\begin{array}{l}\text { Collection period and } \\
\text { data Source }\end{array}$ \\
\hline $\begin{array}{l}\text { Fraser Delta, } \\
\text { BC, Canada }\end{array}$ & 45 & $\begin{array}{l}\text { Strait of } \\
\text { Georgia, } \\
\text { estuary } \\
\text { mouth }\end{array}$ & 24 stations & $\begin{array}{l}\text { not } \\
\text { given; } \\
\text { daily } \\
\text { average }\end{array}$ & $\begin{array}{l}\text { 04/1991-05/1991, } \\
\text { (Gregory 1998); } \\
\text { 04/1999-01/2001; } \\
\text { (Masson 2002) }\end{array}$ \\
\hline $\begin{array}{l}\text { Dungeness } \\
\text { Bay, WA }\end{array}$ & 2 & $\begin{array}{l}\text { Dungeness } \\
\text { River, } \\
\text { estuary } \\
\text { mouth }\end{array}$ & 4 stations & $\begin{array}{l}\text { once a } \\
\text { month, } \\
\text { for } 12 \\
\text { months }\end{array}$ & $\begin{array}{l}\text { 11/1999-10/2000; } \\
\text { (Sargeant 2000) }\end{array}$ \\
\hline $\begin{array}{c}\text { Grays } \\
\text { Harbor, WA }\end{array}$ & 75 & $\begin{array}{l}\text { Upper } \\
\text { estuaries }\end{array}$ & 5 stations & $\begin{array}{c}9 \\
\text { samples } \\
\text { over five } \\
\text { days }\end{array}$ & $\begin{array}{c}\text { 19-21/05/1983; (Kehoe } \\
\text { 1985) }\end{array}$ \\
\hline Ilwaco, WA & 3.5 & Bakers Bay & $\begin{array}{l}4 \text { randomly } \\
\text { positioned } \\
\text { samples }\end{array}$ & $\begin{array}{c}4 \\
\text { samples } \\
\text { daily }\end{array}$ & $\begin{array}{l}\text { 06/1977-03/1978; } \\
\text { (Durkin et al. 1979) }\end{array}$ \\
\hline Astoria, OR & 25 & $\begin{array}{l}\text { Youngs } \\
\text { Bay }\end{array}$ & $\begin{array}{l}4 \text { randomly } \\
\text { positioned } \\
\text { samples }\end{array}$ & $\begin{array}{c}4 \\
\text { samples } \\
\text { a day }\end{array}$ & $\begin{array}{l}\text { 06/1977 and 03/1978; } \\
\text { (Durkin et al. 1979) }\end{array}$ \\
\hline Eureka, CA & 8.2 & $\begin{array}{l}\text { North } \\
\text { Humboldt } \\
\text { Bay }\end{array}$ & $\begin{array}{l}20 \text { sites } \\
\text { along } \\
\text { channel }\end{array}$ & $\begin{array}{l}\text { once per } \\
\text { month }\end{array}$ & $\begin{array}{l}\text { 08/2003-07/2004; } \\
\text { (Pinnix et al. 2001) }\end{array}$ \\
\hline $\begin{array}{l}\text { San } \\
\text { Francisco, } \\
\text { CA }\end{array}$ & 8.6 & $\begin{array}{l}\text { San Pablo } \\
\text { bay, } \\
\text { Central } \\
\text { Bay, South } \\
\text { Bay }\end{array}$ & $\begin{array}{l}4 \text { sample } \\
\text { sites at } 3 \\
\text { locations }\end{array}$ & $\begin{array}{l}\text { once a } \\
\text { month }\end{array}$ & $\begin{array}{l}\text { 10/2000- 01/2001; } \\
\text { (Buchanan \& Ganju } \\
\text { 2001) }\end{array}$ \\
\hline $\begin{array}{l}\text { Half Moon } \\
\text { Bay, CA }\end{array}$ & 3.6 & Beachline & One site & $\begin{array}{c}2 \\
\text { samples } \\
\text { on one } \\
\text { day }\end{array}$ & $\begin{array}{l}2009 \text { (date not given); } \\
\text { (Lean et al. 2010) }\end{array}$ \\
\hline $\begin{array}{c}\text { Moss } \\
\text { Landing, CA }\end{array}$ & 8 & $\begin{array}{l}\text { Elkhorn } \\
\text { Slough } \\
\text { mouth and } \\
\text { within } 20 \mathrm{~m} \\
\text { of river }\end{array}$ & two sites & $\begin{array}{l}\text { once a } \\
\text { month } \\
\text { for } 12 \\
\text { months }\end{array}$ & $\begin{array}{l}\text { 12/1999-09/2001; } \\
\text { (Chapin et al. 2004) }\end{array}$ \\
\hline $\begin{array}{l}\text { Port San Luis, } \\
\text { CA }\end{array}$ & 1.5 & $\begin{array}{l}\text { Along dock } \\
\text { at Alvisa } \\
\text { bay }\end{array}$ & $\begin{array}{c}1 \mathrm{~km} \text { from } \\
\text { shore at } \\
\text { surface and } \\
10 \text { meters } \\
\text { depth }\end{array}$ & $\begin{array}{l}\text { every } \\
\text { half hour } \\
\text { for } 4 \\
\text { hours }\end{array}$ & $\begin{array}{l}\text { 06/2009-08/2009; (Orric } \\
\text { et al. 2009) }\end{array}$ \\
\hline
\end{tabular}


Table 8. Physical and genetic measurements from collection sites.

\begin{tabular}{cccccccc} 
Site & $\begin{array}{c}\text { Opening } \\
\text { L x W }\end{array}$ & $\begin{array}{c}\text { Depth } \\
\text { (m) }\end{array}$ & $\begin{array}{c}\text { Catch } \\
\text { in Tons }\end{array}$ & $\begin{array}{c}\text { Velocity } \\
\left(\mathbf{c m}^{3} / \mathbf{s}\right)\end{array}$ & $\begin{array}{c}\text { Turbidity } \\
\text { (NTU) }\end{array}$ & $\begin{array}{c}\text { Haplotype } \\
\text { diversity } \\
\boldsymbol{h}\end{array}$ & $\begin{array}{c}\text { Nucleotide } \\
\text { diversity } \\
\boldsymbol{\pi}\end{array}$ \\
\hline $\begin{array}{c}\text { Fraser Delta } \\
\text { Dungeness }\end{array}$ & 49.29 & 62 & 5599 & 30 & 45 & 0.63 & 0.003 \\
Bay & 13.30 & 1.4 & $\mathrm{NA}$ & 15 & 2 & 0.87 & 0.008 \\
Gray's Harbor & 16.85 & 10 & 772.5 & 97.74 & 75 & 0.82 & 0.007 \\
Ilwaco & 21.27 & 4 & 6.31 & 87.45 & 3.5 & 0.82 & 0.004 \\
Astoria & 11.70 & 2.5 & $\mathrm{NA}$ & 108.02 & 25 & 0.98 & 0.014 \\
Eureka & 0.61 & 3.6 & 7216 & 2 & 8.2 & 0.95 & 0.008 \\
San Francisco & 30.79 & 41 & 2271 & 80 & 8.6 & 0.84 & 0.006 \\
Half Moon & 27.42 & 9.1 & $\begin{array}{c}\text { Included } \\
\text { above }\end{array}$ & 25 & 3.6 & 0.79 & 0.004 \\
Bay & 21.76 & 7.6 & $\begin{array}{c}92.5 \\
\text { Moss Landing }\end{array}$ & 25 & 8 & 0.86 & 0.006 \\
Port San Luis & 34.24 & 11 & $\begin{array}{c}\text { Included } \\
\text { above }\end{array}$ & 11 & 1.5 & 0.86 & 0.005 \\
\hline
\end{tabular}

Table 9. Statistical description of Skewedness. Skewedness results of physical and genetic measurements as well as Shapiro-Wilk test of normality with p-value used for correlation. Because the NTU dataset was higher than the skewedness threshold of 2.0, it was logarithmically transformed and retested.

\begin{tabular}{lcccccccc} 
& LxW & Depth & Velocity & InNTU & $\boldsymbol{h}$ & $\boldsymbol{\pi}$ & $\boldsymbol{F}_{\text {S }}$ & $\boldsymbol{D}$ \\
\hline Number of cases & 10 & 10 & 10 & 10 & 10 & 10 & 10 & 10 \\
Variance & 184.684 & 400.806 & $1,623.700$ & 1.613 & 0.009 & 0.001 & 27.932 & 0.706 \\
Skewness & 0.427 & 1.920 & 0.454 & 0.930 & -0.917 & 1.598 & -1.507 & 1.232 \\
Shapiro-Wilk Statistic & 0.982 & 0.688 & 0.856 & 0.892 & 0.904 & 0.860 & 0.875 & 0.902 \\
Shapiro-Wilk p-value & 0.976 & 0.001 & 0.069 & 0.177 & 0.243 & 0.077 & 0.114 & 0.228 \\
\hline
\end{tabular}


The comparison of environmental variables with genetic diversities revealed several significant linear relationships (Figure 5). Physical dimensions that did not correlate with the genetic data, include $\operatorname{lnNTU}$ at $\mathrm{r}^{2}=-0.219$ for $h$ and $\mathrm{r}^{2}=0.183$ for nucleotide diversity. In addition, velocity did not correlate with diversity measures (gene diversity and velocity was $r^{2}=0.136$ and nucleotide diversity and velocity was $r^{2}=$ 0.475). Opening size ( $\mathrm{LxW}$ ) related with both gene diversity $(h)$ and to a lesser extent nucleotide diversity $(\pi)$ (simple Pearson's $r^{2}$ was -0.840 for $h$, but $r^{2}=-0.484$ for $\pi$ was not a relationship). When the mean depth of embayments was compared with gene diversity, there was a negative relationship for $h\left(\right.$ Figure $5 ; r^{2}=-0.757$ ) but a lower trend for $\pi\left(r^{2}=-0.434\right)$. 

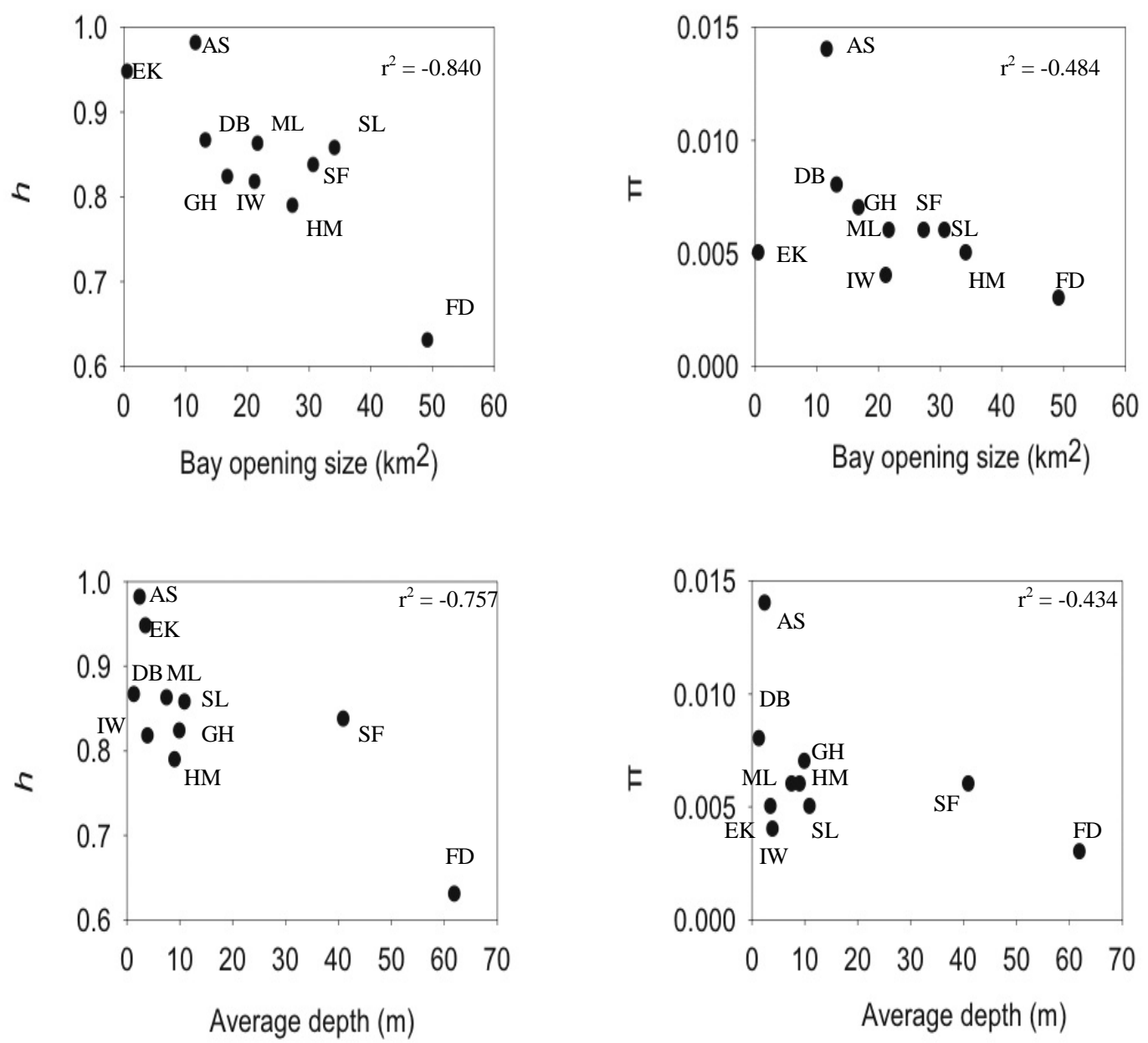

Figure 5. Plots of genetic diversity measures and environmental parameters. Turbidity and velocity data are not shown as there was no obvious relationship. Site abbreviations refer to labels in Table 3A. 
A post hoc analysis was conducted to eliminate alternative explanations, using commercial catch numbers, measured by the ton, for each location (graph not shown) with Tajima's $D$ value and gene diversity $(h)$. The commercial catch in tons plotted against $h$ revealed no relationship with $r^{2}=0.038$. While commercial catch in tons plotted against Tajima's $D$ reveled no relationship with $r^{2}=0.0631$. This suggested that the scaling of harvest intensity did not relate to genetic diversity.

Environmental data were also related to adult population pairwise $F_{\text {ST }}$. Only opening dimensions (LxW) showed a significant correlation (Figure 6). In total, 45 pairwise $F_{\text {ST }}$ data points were compared, corresponding to pairwise $F_{\text {ST }}$ across 10 populations listed in Figure 1. A linear regression procedure indicated a strong negative relationship $\left(r^{2}=-0.67 \mathrm{p}<0.001\right)$ between pairwise $F_{\text {ST }}$ and LxW (Figure 6). Since the comparisons between pairwise $F_{\mathrm{ST}}$ and LxW were not independent measures, the Wilcoxon-signed rank test was used, indicating a significant negative relationship between genetic diversity opening size (Wilcoxon test $\mathrm{Z}$ value $=3.622, \mathrm{p}<0.001$ ) 


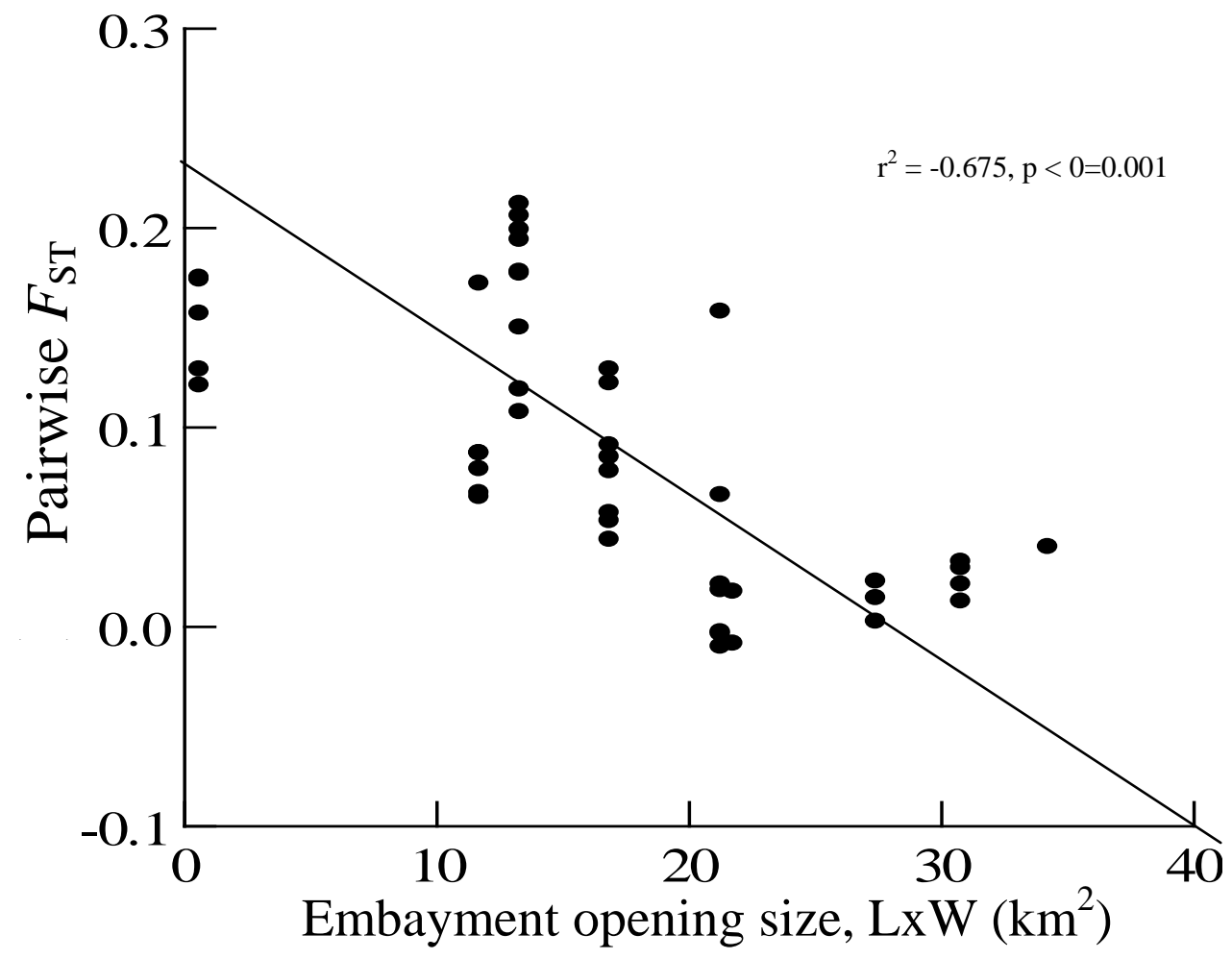

Figure 6. Plot of embayment opening sizes versus $F_{\text {ST. }}$. Robust regression was used to calculate a linear relationship for pairwise $F_{\text {ST }}$ values against embayment opening size $\left(\mathrm{km}^{2}\right)$. Trend line calculated in Systat $\left(\mathrm{r}^{2}=-0.675, \mathrm{p}<0.001\right)$. The Shapiro-Wilk Test $\mathrm{Z}$ value $=3.622$, p-value was $<0.001$. 


\section{Canonical correlation comparison of environmental and genetic relationships}

Canonical correlation analysis showed strong negative relationships between measures of genetic diversity and environmental measures (Figure 7). The high positive canonical loading for environmental measures (loadings chart in Figure 7) indicated that opening LxW was positively related to canonical scores. In addition, the high positive loadings for gene diversity $(h)$ and for Tajima’s $D$ were correlated to opening size canonical scores (Figure 7). The turbidity measure (lnNTU) did relate to genetic variables but was not interpreted because its loading was below a typically accepted threshold (0.424) (data not plotted). The CCA indicated that there was a relationship between the genetic diversity of crabs and the environment in which they obtained. The implication is that coastal terrain has an impact on the genetic measures, in this case, Tajima's $D$ and gene diversity $(h)$. 


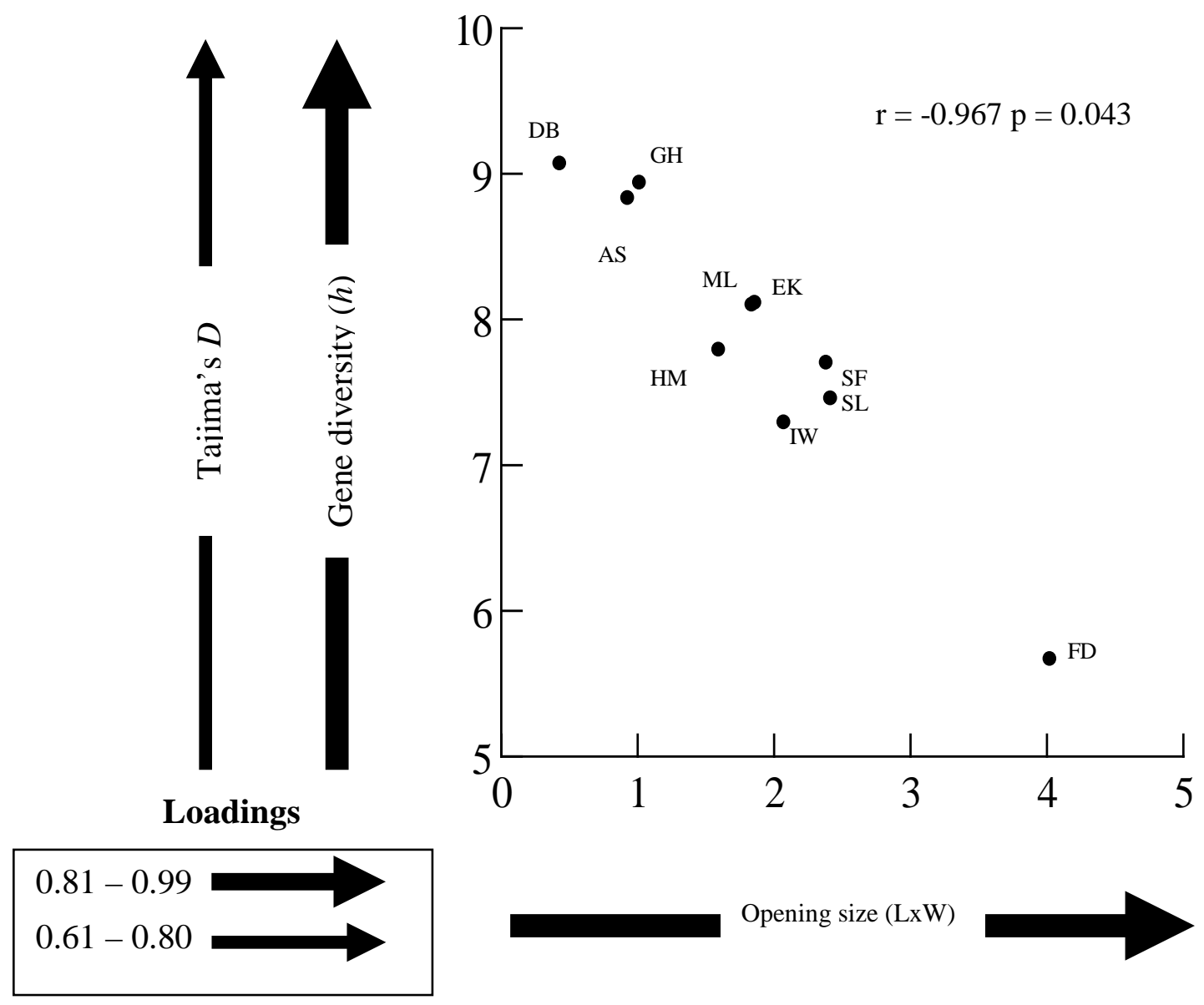

Figure 7. Canonical Correlation Analysis of diversity measures and habitat measures. The plot shows the strongest bivariate correlates. Arrows represent loadings; direction of the arrow indicates the signal of the loading and the thickness of the arrow indicates that absolute value of the loading. Nucleotide diversity $\pi$ showed the same trend as $h$, and depth showed the same trend as LxW. 


\section{DISCUSSION}

Spatial and temporal genetic variation was assessed using mitochondrial DNA from adult and megalopae of Dungeness crabs sampled from Fraser Delta in British Columbia, Washington, Oregon, and California. Megalopae were sampled repeatedly using light traps that were deployed in one location, Coos Bay, OR. Nucleotide $(\pi)$ and gene diversity $(h)$ for the entire adult dataset were 0.010 and 0.850 , COI diversity was uniform and lacking the variance found in adult populations, which is remarkable considering larvae were caught across several years. While this study found no net genetic difference consistent with regional barriers to dispersal, genetic differences were evident in comparing separate years of larval samples (Table 3B) as discussed below.

Given the long distance dispersal of $C$. magister larvae, we expected to find was low to no spatial variation among regions as reported in other studies (Dawson 2001, Petersen 2007, Kelly \& Palumbi 2010), and this was consistent with our $F_{\text {ST }}$ comparisons of adult populations. Secondly, there was no correlation between geographic distances

and genetic distances. Habitat variables, however, were found in some cases to correlate measures of COI diversity. The adult populations sampled in smaller bay tended to have higher diversity $(h)$.

We found a third ecologically significant pattern to diversity. Low diversities of broods of larvae (while warranting further statistical examination) were apparent. This 
observation suggests larvae from the same brood aggregate during dispersal remaining grouped even at settlement (following about 2-month pelagic length dispersal).

\section{No apparent broad scale differentiation}

In sampling extensively over the range of a species, it may be possible to detect distance-limited dispersal, where genetic distances between demes are correlated with their spatial separation, in other words, an Isolation-by-Distance pattern (Wright 1931, Hellberg 1996, Whitlock \& McCauley 1999, Holsinger \& Weir 2009, Weersing \& Toonen 2009). There was no significant fit to the Isolation-by-Distance model, considering adult populations sampled from San Luis Obispo, CA to Frasier Delta, BC with a coastal length covering $1700 \mathrm{~km}$ (Mantel $r=0.059, \mathrm{p}=0.289$ ) or evidence of discrete genetic breaks.

This study suggests accordingly that high gene flow among adult populations leading homogeneity over a large geographic scale (British Columbia to California). The non-significant Mantel and Exact tests showed no relationship between geographic distance and genetic differentiation among population. In addition, AMOVA indicated that variance among regions was non-significant, suggesting no population structure across the C. magister range. Beacham et al. (2008) and Barney (2012) found similar results using COI and microsatellites.

The lack of geographic structure found in this study contrasts with the geographic variation found in the COI gene of Hemigrapsus oregonensis (Petersen 2007), a species with 3-4 week larval dispersal. Petersen did suggest a possible genetic dilution in $C$. 
magister that we observed in this study (2007). C. magister had no obvious barrier to gene flow from British Columbia to California despite some evidence of small scale variance. Similarly to H. oregonensis (Petersen 2007), neutrality tests on both adults and megalopae indicated Dungeness crab went through a recent, post-bottleneck population expansion, likely associated with the most recent glacial relaxation, and accordingly, population samples always consisted of many haplotypes.

\section{High genetic variance among larval collections}

Small-scale spatial variation was evident. The typical pairwise $F_{\text {ST }}$ seen in comparing samples of larvae from Coos Bays by separate years (range: 0.04 - 0.51, mean $=0.33)$ was about three times higher than pairwise $F_{\text {ST }}$

$$
0-0.21 \text {, mean }=0.09 \text { ), as shown in Table } 3 .
$$

AMOVA revealed variation when considering time-sampled within-group populations (see $\Phi_{\mathrm{SC}}$ in Table 6 in all 6 comparisons). These temporal variations could be seen when comparing either adult or megalopae samples. An AMOVA comparing larval samples (pooled across months) among 6 non-consecutive years from Coos Bay, showed a difference being retained over the years: $\Phi_{\mathrm{CT}}=0.212, \mathrm{p}=0.037$. This suggests that diversity is potentially maintained by annual variance of successful recruits. It appears that the complex diversity of adult populations and lack of broad regional distinction are the result of movements of pulses of larvae. Recruitment over time, in other words, dampens genetic differentiation. Temporal variations could be seen when comparing sequences of adult or megalopae samples. An AMOVA comparing larval 
samples (pooled across months) among 6 non-consecutive years from Coos Bay revealed a difference being retained over the years: $\Phi_{\mathrm{CT}}=0.212, \mathrm{p}=0.037$. This suggests that diversity is potentially maintained by annual variance of successful recruits.

\section{Inverse correlation among bay size and genetic diversity}

Species that are isolated in small populations typically have higher rates of divergence with lower diversity than comparable species of larger populations (as suggested by Ohta 1992, Gillespie 1999, 2001, Woolfit \& Bromham 2005). In C. magister, the measured COI sequence diversity was correlated to embayment opening sizes. Analyses the relationship between genetic diversity indices such as $\pi$, Tajima's $D$, and Fu's $F_{\mathrm{S}}$ are still not often considered (e.g. see Wares 2009). We found unexpectedly, small bays tended to have greater genetic diversity than large bays.

The relationship between genetic data and hydrologic features are easily accessible means of identifying potentially high diversity in populations. While COI diversity was negatively related to bay size and depth, the size and depth measures were themselves positively correlated. A canonical correlation analysis in this sense was useful for better understanding trends. The CCA considering bay dimensions and genetic diversity measures ( $\pi, h$, and Tajima's $D$, and Fu's Fs) supported a strong correlation between bay opening size and gene diversity, $h$, with a significant correlation also seen between the opening size and $D$.

The negative correlation between genetic diversity and bay size may be explained a number of ways. Small embayments may allow high survivorship of unique haplotypes 
(i.e., through reduced harvesting), thereby increasing gene diversity measures; or perhaps due to imprecise collection methods of adults, one might see an artifact of sampling ocean shelf habitats with varying diversity patterns.

Perhaps recruitment occurs less often in restricted bays leading to a greater spatial genetic patchiness in these areas. We used the opening size (LxW) to approximate restriction of larval movement in and out of an embayment. This restriction is not a direct measure of the bay water's turnover rate, but still may represent the difficulty of $C$. magister entering and exiting a bay. Further studies comparing artificial coastal drifters and water turnover (e.g. Hickey \& Banas 2003) might show whether a current based model could predict the genetic variance effect that we measured. Accordingly, the mechanism of how hydrology affects genetic diversity is uncertain, and may warrant a focused sampling regime. We do not always have precise sample locations for the adult specimens examined because some samples were obtained entirely or in part from fishing boats. An aspect of the variance might be due to a collection artifact, that is, small bays may harbor vessels that travel outside the bay to bring in their catch. Just as easily, changes in hydrology could be a reasonable explanation for annual variance among Dungeness crab distribution (Galindo et al. 2006).

The maternally inherited mitochondrial data presented in this project will reflect the female effective populations. We found a stronger correlation between bay size and genetic diversity than between regional fishing pressure and diversity. This suggests that overall no effect of harvesting on diversity was obvious. But determining whether an effect could occur is difficult - there have been no comparison of populations present 
prior to commercial harvesting. We observed an unusual genetic signature in the San Francisco populations, where haplotype 2 was not sampled, despite being common elsewhere. Another challenge, which could be addressed in future research, is the need to gain more localized measures of variation in harvest pressure. There may be harvesting related effect in the dataset.

\section{Diversity pattern in the larval pool}

There was a tendency of observing larvae that shared haplotypes in a given light trap collection, which suggests that larvae from the same brood often remain aggregated during dispersal, then recruiting together back into estuaries. The data suggest that often single haplotypes (See Table 4 for the year and weeks where only one or two haplotypes are sampled) appear together during the recruitment period resulting in low diversity. The implication is that a few parents are producing large numbers of offspring and those offspring are maintain kin bonding during 5 to 6 months of open ocean dispersal.

Diversity of larval samples collected together prior to settlement was much lower (2001 $h$ $=0.583$ while $2009 h=0.821$ ) than in adult populations (mean $h=0.851$ ). The relatively low diversity of collected haplotypes in larval samples demonstrates what has been referred to as the "Hedgecock effect” (Waples 1998) - a low diversity of propagules reflecting reproduction by a few mothers in the population. This thesis showed that families of larvae may remain aggregated during 5 months of development. The larval haplotype variation was as low as one haplotype (the pattern reflecting perhaps one mother only) in many samples. Over time however, there was additive variation in the 
reproducing females that resulted in high genetic diversity, with the frequency of long distance dispersal events being sufficiently high, preventing regional patterns of differentiation.

There are multiple plausible explanations for genetic variance among crab populations. Post settlement selection and commercial harvesting may have had significant impacts on a population signal after larval settlement. Contrasting these post selective factors, the current study has shown that variance occurs in megalopae prior to settling.

Hedgecock (1994) predicted that adult diversity would have higher diversity than in the surviving offspring and demonstrated that stochastic environmental factors would determine that a fraction of successful broods return each year. Our results demonstrate that the larval populations sampled have lower $N_{\mathrm{e}}$ than adult populations. This pattern is common in other marine species, including crustaceans, echinoderms, and fish (Hedgecock 1994, Gillespie 2001, Turner et al. 2002). Our study supports Hedgecock’s prediction of reproductive variance, where the diversity of adult populations might be estimated as functions of temporal variation in the alleles present in recruiting megalopae. We showed a higher diversity in adult populations and lower diversity in larval cohorts. This suggests that over all population diversity might be maintained by the influx of lowdiversity sets of larval recruits. Over time, due to the high mortality of offspring year after year, megalopae contribute to a small portion of $C$. magister's overall diversity. Variance among years has been identified in the correlation between hydrology and diversity of local populations. On a local level, the narrow and shallow hydrological 
features of embayments impact the diversity of adult crabs. The mechanism of hydrological features has been discussed in Roegner et al. (2003), where they suggested the Columbia River greatly increased larval distribution. Accordingly, further studies of the genetic variation patterns in larval populations are needed.

In summary, the diversity data of the COI sequence revealed surprising ecological patterns across the range of $C$. magister. Genetic differences accumulated over time are a more likely explanation of adult diversity than the alternative explanation of geographic distribution. In addition to accumulative variance, local hydrological features may also contribute the adult's variance even between nearby populations. 


\section{LITERATURE CITED}

Avise JC, Arnoldt J, Ball RM, Bermingham E, Lambt T, Neigel JE, Reeb CA, Saunders NC (1987) Intraspecific phylogeography: the mitochondrial DNA bridge between population genetics and systematics. Ann Rev Ecol Syst 18:489-522

Barber PH, Palumbi SR, Erdmann MV, Moosa MK (2002) Sharp genetic breaks among populations of Haptosquilla pulchella (Stomatopoda) indicate limits to larval transport: patterns, causes, and consequences. Mol Eco 11:659-674

Barney BT (2012) Microsatellite and mitochondrial DNA analysis of Dungeness crab (Cancer magister) from California to northern British Columbia. MS Thesis. San Jose State University, San Jose, CA

Beacham TD, Supernault J, Miller KM (2008) Population structure of Dungeness crab (Cancer magister) in British Columbia. Jour Shell Res 27(4):901-906

Bergek J \& Olsson K (2009) Spatiotemporal analysis shows stable genetic differentiation and barriers to dispersal in the Eurasian perch (Perca fluviatilis L.).

Evol Ecol Res 11:827-840

Bird CE, Holland BS, Bowen BW, Toonen RJ (2007) Contrasting phylogeography in three endemic Hawaiian limpets (Cellana spp.) with similar life histories. Mol Ecol 16:3173-3186

Botsford LW, Micheli F, Hastings A (2003) Principles for the design of marine reserves. Ecol Appl 13(1):S25-S31

Bowen BW, Bass AL, Muss A, Carlin J, Robertson DR (2006) Phylogeography of two Atlantic squirrelfish (Family Holocentridae): exploring links between pelagic larval duration and population connectivity. Mar Biol 149:899-913 
Buchanan PA \& Ganju NK (2001) Summary of suspended-sediment concentration data, San Francisco Bay, California, water year 2001. U.S. Geological Survey Open-File Report 03-312

Bucklin A, Steinke D, Blanco-Bercial L (2011) DNA Barcoding of marine metazoa. Ann Rev Mar Sci 3:18.11-18.38

Burton RS (1998) Intraspecific phylogeography across the Point Conception biogeographic boundary. Evol 52:735-745

Chapin TP, Caffrey JM, Jannasch HW, Coletti LJ, Haskin JC, Johnson KS (2004) Nitrate sources in Elkhorn Slough, California: results from long term continuous in situ nitrate analyzers. Estuar 27(5): 882-894

Cowen RK, Lwiza KMM, Sponaugle S, Paris CB, Olson DB (2000) Connectivity of marine populations: open or closed? Sci 287:857-59

Cowen RK \& Sponaugle S (2009) Larval dispersal and marine population connectivity. Ann Rev Mar Sci 1:443-466

Dahlstrom WA \& Wild PW (1983) A history of Dungeness crab fisheries in California. Found in Life history, environment, and mariculture studies of the Dungeness crab, Cancer magister, with emphasis on the central California fishery resource. In: Wild PW, Tasto RN (eds) Calif Dep Fish Game Fish Bull 172:197-214

Dawson MN (2001) Phylogeography in coastal marine animals: a solution from California? Jour Biogeo 28:723-736.

Dedhia HJ (2005) Dispersal and phylogeography of Cancer magister using DNA sequencing. MS Thesis. San Jose State University, San Jose, CA

Department of Fish and Wildlife (2013)

http://www.dfg.ca.gov/marine/invertebrate/crabs.asp (accessed 15 Apr 2013) 
Durkin JT, Lipovsky SJ, McConnell RJ (1979) Biological impact of flowlane disposal project near pillar rock in the Columbia river estuary. Natl Mar Fish Serv NOAA Northwest and Alaska Fish Center, Hammond, Oregon, Final Rep U.S. Army Corps of Eng

Doherty PJ, Planes S, Mather P (1995) Gene flow and larval duration in seven species of fish from the Great Barrier Reef. Ecol 76:2373-2391

EPA (2009) Chapter 15 of the volunteer estuary monitoring manual, a methods manual, second edition. Env Prot Act-842-B-06-003:1-15

Excoffier L \& Lischer H (2010) Arlequin suite ver. 3.5: a new series of programs to perform population genetics analyses under Linux and Windows. Mol Ecol Res 10:564567

Excoffier L, Smouse P, Quattro J (1992) Analysis of Molecular Variance inferred from metric distances among DNA haplotypes: application to human mitochondrial DNA restriction data. Gen131:479-491

Fernandez M, Iribarne O, Armstrong D (1993) Habitat selection by young-of-the-year Dungeness crab Cancer magister and predation risk in intertidal habitats. Mar Ecol Prog Ser 92:171-177

Flowers JM, Schroeter SC, Burton RS (2002) The recruitment sweepstakes has many winners: genetic evidence from the sea urchin Stronglylocentrotus purpuratus. Evol 56(7):1445-1453

Fu YX and Li WH (1993) Statistical tests of neutrality of mutations. Gen 133:693-709

Fu YX (1997) Statistical tests of neutrality of mutations against population growth, hitchhiking, and background selection. Gen 147:915-925

Gillespie JH (1999) The role of population size in molecular evolution. Theor Pop Biol 55:145-156 
Gillespie JH (2001) Is the population size of a species relevant to its evolution? Evol 55:2161-2169

Galindo HM, Olson DB, Palumbi SR (2006) Seascape genetics: a coupled oceanographic-genetic model predicts population structure of caribbean corals. Cur Biol 16:1622-1626

Galindo HM, Pfeiffer-Herbert AS, McManus MA, Chao Y, Chai F, Palumbi SR (2010) Seascape genetics along a steep cline: using genetic patterns to test predictions of marine larval dispersal. Mar Ecol Prog Ser 19(17):3692-707

Gregory RS \& Levings CD (1998) Turbidity reduces predation on migrating juvenile Pacific salmon. Trans Amer Fish Soc 127:275-285

Harpending RC (1994) Signal of ancient population growth in a low-resolution mitochondrial Mismatch Distribution. Hum Biol 66:591-600

Harrison MK \& Crespi BJ (1999) Phylogenetics of Cancer crabs (Crustacea: Decapoda: Brachyura). Mol Phylo and Evol 12:186-199

Hedgecock D (1994) Temporal and spatial genetic structure of marine animal populations in the California current. Calif Coop Ocean Fish Invest Rep 35:73-81

Hedgecock D \& Pudovkin AI (2011) Sweepstakes reproductive success in highly fecund marine fish and shellfish: a review and commentary. Bull Mar Sci 87(4):971-1002

Hellberg ME (1996) Dependence of gene flow on geographic distance in two solitary corals with different larval dispersal capabilities. Evo 50(3):1167-1175

Hellberg ME (2009) Gene flow and isolation among populations of marine animals. Annu Rev Ecol Evol Syst 40:291-310 
Hellberg ME, Balch DP, Kaustuv R (2001) Climate-driven range expansion and morphological evolution in a marine gastropod. Sci 292:1707-1710

Hickey BM \& Banas NS (2003) Oceanography of the U.S. Pacific Northwest coast and estuaries with application to coastal ecology. Estuar 26:1010-1031

Holsinger KE \& Weir BS (2009) Genetics in geographically structured populations:

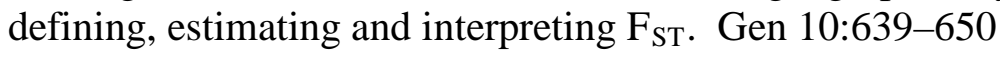

Jensen GC \& Armstrong DA (1987) Range extensions of some Northeastern Pacific Decapoda. Crust 52(2):215-217

Johnson MS \& Black R (1982) Chaotic genetic patchiness in an intertidal limpet, Siphonaria sp. Mar Biol (70):157-164

Kehoe DM (1985) Effects of Grays Harbor estuary sediment on the osmoregulatory ability of Coho salmon smolts (Oncorhynchus kisutch). Bull Environ Contam Toxicol 30:522-529

Kelly RP \& Palumbi SR (2010) Genetic structure among 50 species of the northeastern Pacific rocky intertidal community. PLoS ONE 5(1):1-13.

Kinlan BP \& Gaines SD (2003) Propagule dispersal in marine and terrestrial environments: a community perspective. Ecol 84(8):2007-2020

Kinlan BP, Gaines SD, Lester SE (2005) Propagule dispersal and the scales of marine community process. Diver Distrib 11:139-148

Kimura M (1980) A simple method for estimating evolutionary rate of base substitutions through comparative studies of nucleotide sequences. Jour Mol Evol 16:111-120

Knowlton N \& Keller BD (1993) Divergence in proteins, mitochondrial DNA, and reproductive compatibility across the Isthmus of Panama. Sci 260(5114):1629-1632 
Knowlton N \& Weigt LA (1998) New dates and new rates for divergence across the Isthmus of Panama. Proc Roy Soc Lond B 265:2257-2263

Kreader CA (1996) Relief of amplification inhibition in PCR with Bovine Serum Albumin or T4 gene 32 Protein. Appl and Envir Microb 62:1102-1106

Kuzmin S, Olsen S, Gerasimova O (1996) Barents Sea king crab (Paralithodes camtschaticus): transplantation experiments were successful. High Lat Crabs Biol Manag and Econ AK 649-663

Lardy CH (2006) Biogeographical genetic variation of the Dungeness crab (Cancer magister). MS Thesis. San Jose State University, San Jose, CA

Lean MH, Seo J, Kole A, Völkel AR, Chang N, Melde K (2010) Innovative costeffective pre-treatment for desalination. Clean Technology 2010, Palo Alto Research Center, Palo Alto, CA p 336-338

Levitan DR (2005) The distribution of male and female reproductive success in a broadcast spawning marine invertebrate. Integr Comp Biol 45:848-855

Li G \& Hedgecock D (1998) Genetic heterogeneity, detected by PCR-SSCP, among samples of larval Pacific oysters (Crassostrea gigas) supports the hypothesis of large variance in reproductive success. Can Jour Fish Aqua Sci 55(4):1025-1033

Manel S, Schwartz MK, Luikar G, Taberlet P (2003) Landscape genetics: combining landscape ecology and population genetics. Trends Ecol Evol 18:189-197

Mantel N (1967) The detection of disease clustering and a generalized regression approach. Canc Res 27(2):209-220

Marko PB (2004) ‘What's larvae got to do with it?’ Disparate patterns of post-glacial population structure in two benthic marine gastropods with identical dispersal potential. Mol Ecol 13:597-611 
Masson D (2002) Deep water renewal in the Strait of Georgia. Estuar Coast Shelf Sci 54(1):115-126

McLaren IA (1963) Effects of temperature on growth of zooplankton, and the adaptive value of vertical migration. Jour Fish Res Board Cana 20(3):685-727

Miller JA \& Shanks AL (2004) Ocean-estuary coupling in the Oregon upwelling region: abundance and transport of juvenile fish and of crab megalopae. Mar Ecol Prog Ser 271:267-279

Moloney CL, Botsford LW, Largier JL (1994) Development, survival, and timing of metamorphosis of planktonic larvae in a variable environment, the Dungeness crab as an example. Mar Ecol Prog Ser 113:61-79

Mousset S, Derome N, Veuille M (2004) A test of neutrality and constant population size based on the Mismatch Distribution. Mol Biol Evol 21(4):724-731

Myre E \& Shaw R (2006) The turbidity tube: simple and accurate measurement of turbidity in the field. In: Myre, Shaw (eds) Michigan Technological University http://www.mtu.edu/cee/ department/alumni/publications/pdf/cee-2006.pdf (assessed 12 Dec 2011)

Nei M (1986) Definition and estimation of fixation indices definition and estimation of fixation indices. Evol 40:643-645

Ng PKL, Guinot D, Davie PJF (2008) Systema brachyurorum: part I. an annotated checklist of extant brachyuran crabs of the world. Raffl Bull Zool 17:1-286

National Oceanic and Atmospheric Administration (NOAA) Nautical Chart On-Line Viewer http://www.charts.noaa.gov/OnLineViewer/PacificCoastViewerTable.shtml (accessed 13 Nov 2011)

National Oceanic and Atmospheric Administration (NOAA) National Data Bouy Center (NDBC) database http://www.ndbc.noaa.gov/adcp.shtml (accessed 20 Nov 2011). 
Ohta T (1992) The nearly neutral theory of molecular evolution. Annu Rev Ecol Syst 23:263-286

Orrico CM, Moline MA, Robbins I, Zelenke B, Barnard AH, Strubhar W, Koegler J, Moore C (2010) A new tool for monitoring ecosystem dynamics in coastal environments: long-term use and servicing requirements of the commercial Underwater

Bioluminescence Assessment Tool (U-BAT) WET Labs, Inc. Pub. California Polytechnic State University Biological Sciences Department San Luis Obispo, CA 1-6

Palumbi SR (1994) Genetic divergence, reproductive isolation, and marine speciation. Annu Rev Ecol Syst 25:547-72

Palumbi SR (2003) Population genetics, demographic connectivity, and the design of marine reserves. Ecol Appl 13:146-158

Pauley GB, Armstrong DK, Van Citter R, Thomas GL (1989) Species profiles: life histories and environmental requirements of coastal fishes and invertebrates (Pacific Southwest)—Dungeness crab. US Fish Wild Sew Biol Rep 82(11.121). US Army Corps of Engineers, TR EL-82-4

Petersen C (2007) Historical demography and contemporary spatial genetic structure of an estuarine crab in the northeast Pacific (Hemigrapsus oregonensis). Mar Biol 150:6 1289-1300

Pielou EC (1992) After the ice age: The return of life to glaciated North America. Geoarch 7(4):397-400

Pillar SC, Armstrong DA, Hutchings L (1989) Vertical migration, dispersal and transport of Euphausia lucens in the southern Benguela current. Mar Ecol Prog Ser 53:179-190

Pinnix WD, Shaw TA, Acker KC, Hetrick NJ (2005) Fish communities in eelgrass, oyster culture, and mudflat habitats of North Humboldt Bay, California Final Report. US Fish and Wildlife Service, Arcata Fish and Wildlife Office, Arcata Fisheries Technical Report Number TR2005-02, Arcata, CA 1-55 
Raymond M \& Rousset RF (1995) An exact test for population differentiation. Evol 49:1280-1283

Roegner GC, Armstrong DA, Hickey BH, Shanks AL (2003) Ocean distribution of Dungeness crab megalopae and recruitment patterns to estuaries in Southern Washington State. Estu 26(4B):1058-1070

Roegner GC, Armstrong DA, Shanks AL (2007) Wind and tidal influences on larval crab recruitment to an Oregon estuary. Mar Ecol Prog Ser 351:177-188

Rogers AR (1995) Genetic evidence for a Pleistocene population explosion. Evol 49:608-615

Rogers AR \& Harpending H (1992) Population growth makes waves in the distribution of pairwise genetic differences. Mol Biol Evol 9:552-569

Sargeant D (2000) Quality assurance project plan for Dungeness river/Matriotti creek fecal coliform bacteria total maximum daily load study. Washington State Department of Ecology Environmental Assessment Program Watershed Ecology Section 1-16

Schneider S \& Excoffier L (1999) Estimation of past demographic parameters from the distribution of pairwise differences when the mutation rates vary among sites: application to human mitochondrial DNA. Gen 152:1079-1089

Selkoe KA, Henzler CM, Gaines SD (2008) Seascape genetics and the spatial ecology of marine populations. Fish and Fish 9:363-377

Shanks A (1986) Vertical migration and cross-shelf dispersal of larval Cancer spp. and Randallia ornata (Crustacea: Brachyura) off the coast of southern California. Mar Biol 92:189-199

Shanks A (2006) Mechanisms of cross-shelf transport of crab megalopae inferred from a time series of daily abundance. Mar Biol 148:1383-1398 
Shanks A (2009) Pelagic larval duration and dispersal distance revisited. Biol Bull 216:373-385

Shanks AL, Grantham BAG, Carr MHC (2003) Propagule dispersal distance and the size and spacing of marine reserves. Ecol Appl 13(1):S159 -S169

Shanks AL \& Roegner CG (2007) Recruitment limitation in Dungeness crab populations is driven by variation in atmospheric forcing. Ecol 88:1726-1737

Shapiro SS \& Wilks MB (1965) An analysis of variance test for normality (complete samples). Biom 52(3-4):591-611

Schmitt T (2007) Molecular biogeography of Europe: Pleistocene cycles and postglacial trends. Front Zool 4(11):1-13

Slatkin M (1985) Rare alleles as indicators of gene flow. Evol 39(1):53-65

Slatkin M (1991) Inbreeding coefficients and coalescence times. Genet Res Camb 58:167-175

Sotka EE, Wares JP, Barth JA, Grosberg RK, Palumbi, SR (2004) Strong genetic clines and geographical variation in gene flow in the rocky intertidal barnacle (Balanus glandula). Mol Ecol 13:2143-2156

Swearer SE, Shima JS, Hellberg ME, Thorrold SR, Jones GP, Robertson DR, Morgan SG, Selkoe KA, Ruiz GM, Warner RR (2002) Self-recruitment in demersal marine populations. Bull Mar Biol 70(1):251-271

Tajima F (1989) Statistical method for testing the neutral mutation hypothesis by DNA polymorphism. Genet, 123:585-595 
Tamura K, Dudley J, Nei M, Kumar S (2007) MEGA4: Molecular Evolutionary Genetics Analysis (MEGA) software version 4.0. Mol Biol Evol 24:1596-1599

Toonen RJ \& Grosberg RK (2003). Molecular genetic analysis of recruitment pstterns in the Dungeness crab, Cancer magister. UC San Diego: Cali Sea Grant Col Prog. http://www.escholarship.org/uc/item/8v42t937 (accessed 10 Oct 2010)

Trakhtenbrot A, Nathan R, Perry G, Richardson DM (2005) The importance of longdistance dispersal in biodiversity conservation. Diver Distr 11:173-181

Turner TF, Richardson LR, Gold JR (1999) Temporal genetic variation of mitochondrial DNA and the female effective population size of red drum (Sciaenops ocellatus) in the northern Gulf of Mexico. Mol Ecol 8:1223-1229

Turner TF, Wares J, Gold J (2002) Genetic effective size is three orders of magnitude smaller than adult census size in an abundant, estuarine-dependent marine fish (Sciaenops ocellatus). Gen 162:1329-1339

Waples RS (1998) Separating the wheat from the chaff: patterns of genetic differentiation in high gene flow species. Journ Hered 89(5): 438-450

Waples RS, Punt AE, Cope JM (2008) Integrating genetic data into management of marine resources: how can we do it better? Fish 9:423-449

Wares JP (2009) Natural distributions of mitochondrial sequence diversity support new null hypotheses. Evol 64-4:1136-1142

Warner RR \& Cowen RK (2002) Local retention of production in marine populations: evidence, mechanisms, and consequences. Bull Mar Biol 70(1S):245-249

Washington Department of Fish and Wildlife (2013) http://wdfw.wa.gov/fishing/commercial/crab/coastal/landings.html\#area http://www.dfg.ca.gov/marine/invertebrate/crabs.asp (accessed 15 Apr 2013) 
Weersing K \& Toonen RJ (2009) Population genetics, larval dispersal, and connectivity in marine systems. Mar Ecol Prog Ser 393:1-12

Weir BS \& Cockerham CC (1984) Estimating F-statistics for the analysis of population. Evol 38:1358-1370

White T (1994) Monitoring a watershed: nationwide turbidity testing in Australia. Volun Monit 6(2):22-23

Whitlock MC \& McCauley DE (1999) Indirect measures of gene flow and migration: FST 1/(4Nm+1). Hered 82:117-125

Wilcox RR (1998) How many discoveries have been lost by ignoring modern statistical methods? Amer Psych 53:300-314

Wilcoxon, Frank (1945). Individual comparisons by ranking methods. Biom Bull 1(6):80-83

Wild PW (1980) The influence of seawater temperature on spawning, egg development, and hatching success of the Dungeness crab, Cancer magister. In: Wild PW, Tasto RN (eds) Life history, environment, and mariculture studies of the Dungeness crab, Cancer magister, with emphasis on the central California fishery resource. Calif Dept Fish Game Fish Bull 172:197-214

Wing SR, Botsford LW, Largier JL, Morgan LE (1995) Spatial structure of relaxation events and crab settlement in the northern California upwelling system. Mar Ecol Prog Ser 128:199-211

Woolfit M \& Lindell Bromham L (2005) Population size and molecular evolution on islands. Proc R Soc B doi:10.1098/rspb.2005.3217 published online (accessed 12 Dec 2012)

Wright S (1931) Evolution in Mendelian populations. Gen 16:97-159 
Wright S (1943) Isolation by distance. Gen 28:114-138

Yonis R (2010) The economics of British Columbia's crab fishery: socio-economic profile, viability, and market trends. Pub: Policy Branch, Pacific Region Fisheries and Oceans Canada Vancouver, British Columbia. Statistical and Economic Analysis Series. 1-4: 1-24 http://www.dfo-mpo.gc.ca/ea-ae/cat1/no1-4/no1-4-eng.htm (accessed 15 Apr 2013) 